\title{
The ash-fall hazard from a Plinian eruption at Colima Volcano, Mexico
}

\author{
Rita Fonseca ${ }^{1,{ }^{\star}}$ and Ana Lillian Martin Del Pozzo ${ }^{1}$ \\ ${ }^{1}$ Instituto de Geofisica, Universidad Nacional Autónoma de México, Ciudad Universitaria, Coyoacan Mexico D.F., Mexico
}

\author{
Article history \\ Received November 15, 2010; accepted November 23, 2010. \\ Subject classification: \\ Volcanology, Volcanic risk, Ash-fall hazard, Colima Volcano, Mexico.
}

\section{ABSTRACT}

The historical eruptive activity at Colima Volcano has been characterized by Strombolian and Merapi type eruptions and Vulcanian explosions associated with dome growth, which have ended in a Plinian eruption about every 100 years. The situation now prevailing at Colima Volcano is similar to that which preceded these explosive eruptions, when a dome fills the crater. This study proposes seven scenarios for the ash-fall from a Plinian eruption, based on historical eruptive activity, isopach thickness from the 1913 Plinian eruption, land use, socioeconomic data, and a 15year statistical wind study realized with daily radiosonde data grouped according to four altitudinal levels: 4,000-9,000 (I); 9,000-14,000 (II); 14,000-17,000 (III) and 17,000-28,000 (IV) m a.s.l., based on common wind speeds and directions. We have integrated the wind distribution at level IV and estimated the ash dispersion for a Plinian eruption. From January to March, the main impact would be towards the northeast, in April and in October, towards the east, in May, towards the north-northeast or northnorthwest, from June to August, towards the northwest, in September, towards the west, and in November and December, towards the westsouthwest. The fallout would damage the coniferous forests of the Colima National Park, two lagoons and three lakes. More than 30 million people living in Guadalajara, Mexico City, Leon and Colima would suffer eye, respiratory and skin problems. The proximal areas, such as Ciudad Guzman, would be subject to roof collapsing and communication problems. The agricultural and livestock sectors would suffer severe financial losses. The Queseria sugar mill, the Atenquique paper mill, and the cement plants in Zapotiltic would halt work due to chimney obstruction and machinery abrasion. Four thermoelectric plants, twenty airports and four commercial ports would be affected if the eruption occurs in summer.

\section{Introduction}

Colima Volcano (CV; $\left.19^{\circ} 30^{\prime} 44^{\prime \prime} \mathrm{N} ; 103^{\circ} 37^{\prime} 02^{\prime \prime} \mathrm{W}\right)$ is located in the western part of the Trans-Mexican Volcanic Belt at nearly 4,000 $\mathrm{m}$ above sea level (a.s.l.), and it is one of the most active volcanoes in Mexico (Figure 1). According to detailed historical analysis and field work, Plinian eruptions of CV have occurred on the order of once every 100 years. These have had significant impact on the surrounding areas because of widespread fall deposits, surges and pyroclastic flows that destroyed farms, and caused roof collapses, forest fires, loss of livestock and crops, contamination of water resources, and morphological changes to the ravines and crater [Waitz 1932, Lugo et al. 1993, Martin Del Pozzo et al. 1995a, Saucedo 1997]. The last of these eruptions was characterized by an eruptive column over $23 \mathrm{~km}$ high, and it occurred in 1913, causing darkness in Ciudad Guzmán, Sayula and Guadalajara, which are located between $26 \mathrm{~km}$ and $140 \mathrm{~km}$ from CV [Arreola 1915, Saucedo et al. 2010]. The area covered by the ash at that time is now populated by more than 5 million people.

The present-day activity at $\mathrm{CV}$ is associated with dome growth and destruction of the crater, which has become more explosive after several decades of lava emission. These Vulcanian eruptions are similar to those that preceded the Plinian eruptions, suggesting the possibility of a Plinian phase in the near future, like those that occurred in 1818 and 1913. In this study, we identify and evaluate the areas that will be vulnerable to ash-fall in Plinian eruption scenarios, based on analyses of historical eruptive activity, isopach thickness from the 1913 eruption, a vertical wind study, and socioeconomic characteristics of the cities involved. Ash-fall would form secondary lahars by obstructing the steep ravines on $\mathrm{CV}$, especially during the summer. Furthermore, the steep upper slope of the CV cone and its growth on the older Nevado de Colima and collapsed CV, represent unstable conditions for its southern flank [Lugo et al. 1993, Martin Del Pozzo et al. 1995a, Cortes et al. 2005].

\section{Methodology}

A detailed revision of historical and current documents regarding the volcanic activity of $\mathrm{CV}$ was carried out to evaluate its eruptive behaviour. Field work allowed us to identify the explosive deposits of the 1818 and 1913 eruptions and their distribution.

Considering the possibility of a new explosive event, a wind study was carried out, based on the 15-year radiosonde database (1990-2005) from the Manzanillo station of the 


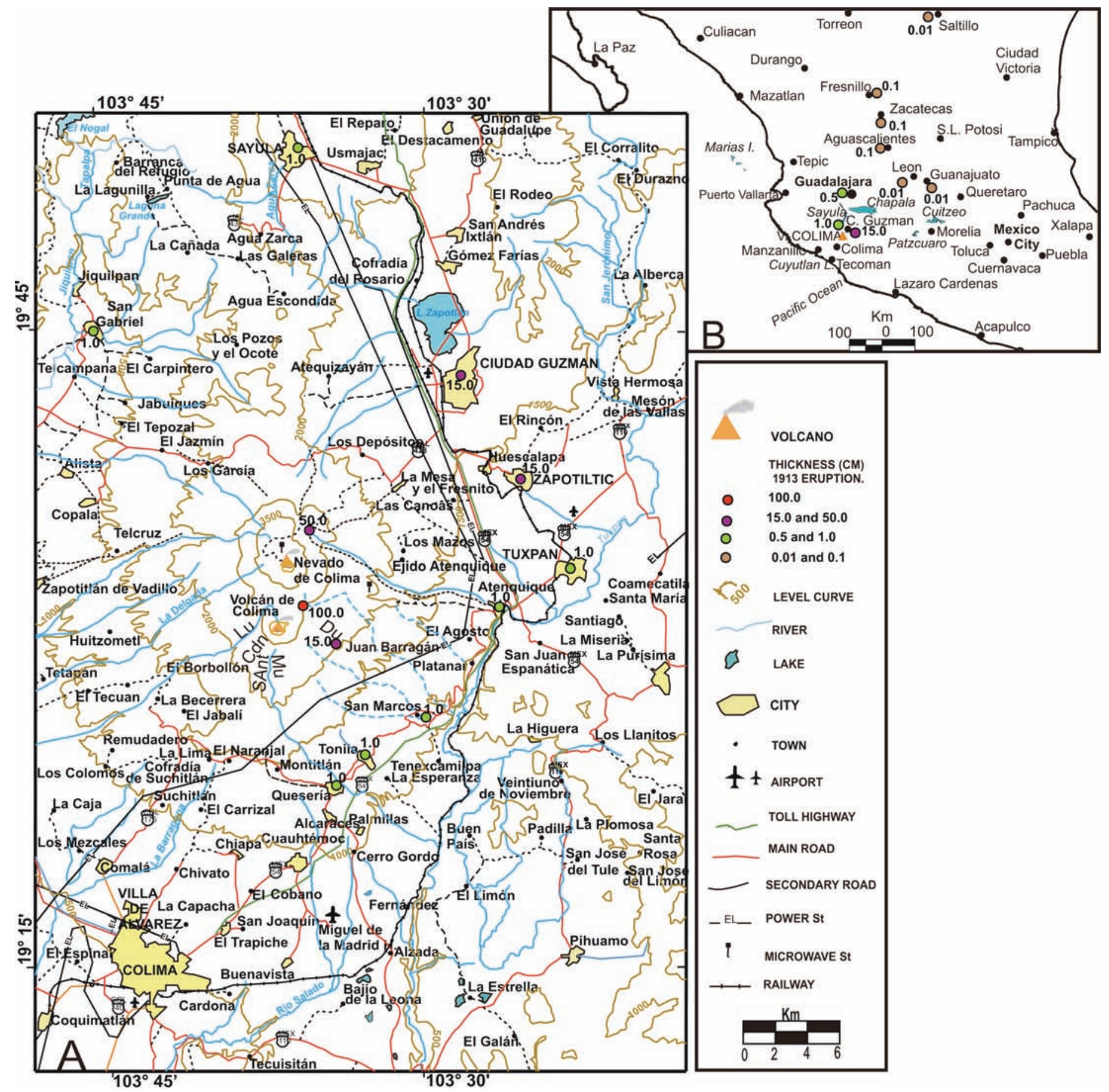

Figure 1. A: Map of the Colima Volcano and cities affected in 1913 by ash fall. Lu: La Lumbre; SAnt: San Antonio; Mu: El Muerto; Du: Durazno; Cdn: Cordoban. B: Localitation of Volcano in Mexico.

National Meteorological Service $\left(19^{\circ} 07^{\prime} \mathrm{N}, 103^{\circ} 33^{\prime} \mathrm{W}\right)$, and complemented with data from the Guadalajara station $\left(20^{\circ} 39^{\prime} 57^{\prime \prime} \mathrm{N}, 103^{\circ} 22^{\prime} 48^{\prime \prime} \mathrm{W}\right)$. The statistical analysis was based on the daily radiosonde database, which has 15 pressure levels and includes wind direction (degrees), wind intensity $(\mathrm{m} / \mathrm{s})$ and altitude $(\mathrm{m})$. The wind dataset was then organized into four altitudinal levels: I, 4,000-9,000; II, 9,00014,000; III, 14,000-17,000; and IV, 17,000-28,000 $\mathrm{m}$ a.s.1. These were subdivided according to the variations in wind speed and direction. Levels I and II showed wind-speed variations of between $100 \mathrm{~km} / \mathrm{h}$ and $150 \mathrm{~km} / \mathrm{h}$. For levels III and IV, the wind-speeds were $150 \mathrm{~km} / \mathrm{h}$. These data are also consistent with the regional atmospheric circulation model [Fonseca et al. in preparation].

Scenarios for future Plinian eruptions with a height of $23 \mathrm{~km}$ were prepared for each month, by integration of historical and socioeconomic characteristics per city, field data of ash isopach distribution of the 1913 eruption, and dominant monthly wind vectors at 17,000-28,000 $\mathrm{m}$ a.s.1. These are all plotted on 1:250,000 and 1:1,000,000 scale maps. The socioeconomic data (population, economic activity, airport type, flights / year, roads, power stations) was based on the 2005 census [INEGI 2005] and the statistical yearbook [INEGI 2007]. 


\section{Population and infrastructure}

The CV region was the seat of pre-Colombian cultures that flourished in western Mexico, and the volcanic activity was not an obstacle for the socioeconomic development of the area.

In the 1913 eruption, more than 732,426 inhabitants were affected by ash-fall, while from 1913 to 2005, the population in the same area increased to more than 5 million people (Table 1). Ash also fell on Mexico City in 1818, which now has more than 20 million inhabitants. Other cities, like Guadalajara and Leon, had ash-falls in 1770 and 1913, and they now have more than 4 million and 1.3 million inhabitants, respectively.

The CV is a National Park, and it also includes agricultural land and ranches. Private environmental protection areas, such as El Borbollon, the Jabalí ranch, and the Hacienda San Antonio Hotel, are located from between $9 \mathrm{~km}$ and $12 \mathrm{~km}$ from CV. During the field work, we confirmed that the Borbollon and Jabalí ranches have sustainable management of natural resources and employ local people. Perception of the volcanic hazard has strengthened the communication between the people working in these locations and the authorities.

The permanent crops are mainly fruit, vegetables, cereals, sugar cane and agave, which have important roles in both the local and regional economies. Sugar cane is the main crop, which supplies the Queseria sugar mill that is located $15 \mathrm{~km}$ from CV. The El Borbollon ranch grows coffee, which is sold in the city of Colima. In San Marcos, $15 \mathrm{~km}$ from CV, there is a greenhouse that grows exotic flowers for export. Most of the population works in farming, trade, administration services, tourism and construction.

There are a total of 14 international airports in the cities of Aguascalientes, Guadalajara, Leon, Manzanillo, Mazatlán, México City, Morelia, Puebla, Puerto Vallarta, Querétaro, San Luis Potosi, Saltillo, Toluca and Zacatecas, all of which are within $725 \mathrm{~km}$ of $\mathrm{CV}$, and are included in the area that experienced ash-fall in 1913 (Table 2). There are also six national airports in the cities of Zamora, Celaya, Colima, Tepic, Uruapan and Cuernavaca. Even with small eruptions, such as those in May 2001 and September 2005, the airport in the city of Colima was closed due to ash-fall. With larger events, the ash-fall would damage aeroplanes and power plants, and disrupt airports, causing short circuits in computers and burning out transformers [Guffanti et al. 2009]. Due to its abrasive nature, ash is hazardous to aeroplane electronic communication systems, turbines and fuselage [Casadevall 1992].

The main roads in the area have constant traffic, such as the Federal and Panamerican highways that connect Colima, Guadalajara and México City with northern Mexico. The thermoelectric plants in Manzanillo, Mazatlán, Acolman,

\begin{tabular}{|c|c|c|c|c|}
\hline \multirow{2}{*}{$\begin{array}{l}\text { Ash fall } \\
\text { thickness } \\
\text { (cm) }\end{array}$} & \multirow{2}{*}{ Cities } & \multirow{2}{*}{$\begin{array}{l}\text { Distance } \\
\text { to crater } \\
(\mathrm{km})\end{array}$} & \multicolumn{2}{|c|}{ Population } \\
\hline & & & 1913 & 2005 \\
\hline \multirow[t]{2}{*}{15} & Ciudad Guzmán & 26 & 17,085 & 93,609 \\
\hline & Zapotiltic & 24 & 3,648 & 21,440 \\
\hline \multirow[t]{3}{*}{$>1$} & Queseria & 15 & 963 & 8,079 \\
\hline & Sayula & 41 & 78,720 & 27,311 \\
\hline & Tuxpan & 25 & 4,472 & 26,134 \\
\hline \multirow[t]{6}{*}{0.5} & Atotonilco el Alto & 160 & 6,027 & 26,044 \\
\hline & Aguascalientes & 320 & 76,591 & 663,671 \\
\hline & Guadalajara & 140 & 119,468 & $4,295,853$ \\
\hline & Sahuayo & 111 & * & 59,316 \\
\hline & Tamazula & 42 & * & 17,441 \\
\hline & Tizapan el Alto & 93 & 1,922 & 13,755 \\
\hline \multirow[t]{8}{*}{0.1} & Arandas & 185 & 5,911 & 46,099 \\
\hline & Barca, La & 150 & 7,487 & 33,653 \\
\hline & Encarnación de Díaz & 250 & 4,711 & 22,902 \\
\hline & Fresnillo & 440 & 60,822 & 110,892 \\
\hline & Lagos de Moreno & 257 & 12,243 & 92,716 \\
\hline & Teocaltiche & 240 & 5,840 & 21,661 \\
\hline & Tepatitlán & 185 & 5,560 & 82,975 \\
\hline & Yahualica & 200 & 3,036 & 14,265 \\
\hline \multirow[t]{7}{*}{0.01} & Ameca & 122 & 9,529 & 35,047 \\
\hline & Guanajuato & 312 & 66,933 & 70,798 \\
\hline & León & 275 & 89,510 & $1,278,087$ \\
\hline & Piedad, La & 190 & 25,790 & 78,361 \\
\hline & Saltillo & 720 & 25,414 & 633,667 \\
\hline & Zamora & 145 & 97,994 & 127,606 \\
\hline & Zapotlanejo & 145 & 2,750 & 30,162 \\
\hline
\end{tabular}

Based on: Dirección General de Secretaria de Hacienda y Fomento de Estadistica (1918) and INEGI (2005).

Table 1. Main cities affected by the 1913 eruption, and the populations in 1913 and 2005.

\begin{tabular}{lll}
\hline City & International Airport & Flights/year \\
\hline Aguascalientes & Jesús Terán Pereda & 11,506 \\
Cuernavaca & Gral. Mariano Matamoros & no data \\
Durango & Gral. Guadalupe Victoria & 15,676 \\
Guadalajara & Miguel Hidalgo y Costilla & 136,206 \\
Leon & El Bajío & 27,206 \\
Manzanillo & Manzanillo & 8,004 \\
Mazatlán & Rafael Buelna & no data \\
Mexico City & Benito Juárez & 355,593 \\
Morelia & Francisco Mujica & 18,144 \\
Pachuca & Juan G. Villasana & no data \\
Puebla & Hermanos Serdán & 17,277 \\
Puerto Vallarta & Gustavo Díaz Ordaz & 38,892 \\
Querétaro & Querétaro & 12,733 \\
Saltillo & Ramos Arizpe & 13,165 \\
San Luis Potosí & Ponciano Arriaga & 23,071 \\
Toluca & Adolfo Lopez Mateos & no data \\
Victoria Ciudad & Gral. Pedro José Méndez & no data \\
Zacatecas & Gral. Leobardo C. Ruiz & 8,257 \\
\hline City & National Airport & Flights/year \\
\hline Celaya & Celaya & 2,400 \\
Colima & Miguel de la Mardrid H & 5,207 \\
Tepic & Amado Nervo & 10,837 \\
Uruapan & lgnacio López Rayón & 6,010 \\
Zamora & Zamora & 1,061 \\
\hline & &
\end{tabular}

Table 2. List of cities with airports and number of flights per year (2006 data).

north of Mexico City, Salamanca, San Luis Potosí, Tepic and Tula are important sources of income, as are the petrochemical and refinery industries in Salamanca, Veracruz and Tepic. The power stations in Colima, Manzanillo and Guadalajara supply more 1.5 million consumers with electricity, and these might be affected in the future by a Plinian eruption. 


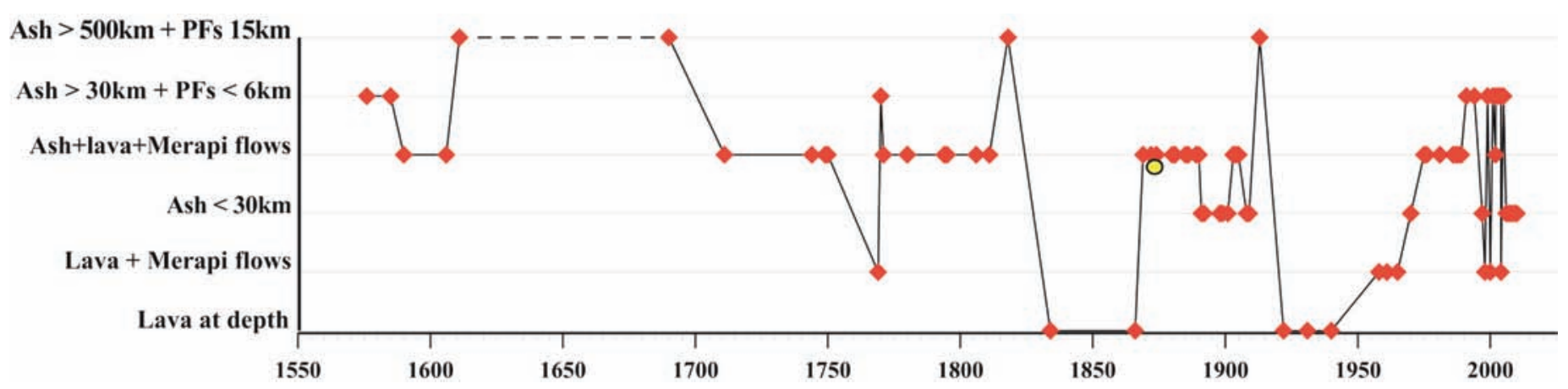

Figure 2. Colima Volcano historical activity. Based on: Tello 1651, Perez de Leon 1789, Mota Padilla 1742, Bárcena 1887, Puga 1889, Vizcarra 1891, Starr and Arreola 1903, Diaz 1906, Arreola 1915, Waitz 1932, Mooser 1961, Thorpe et al. 1977, Luhr and Carmichael 1982, Medina 1983, Flores 1987, Martin Del Pozzo and Romero 1988, De la Cruz 1993, Vizcaino 1993, Martin del Pozzo et al. 1995b, García-Acosta and Suárez 1996, Saucedo 1997, Breton et al. 2002, Reyes and De la Cruz 2002, Zobin et al. 2002, Navarro et al. 2003, Smithsonian Institution [1988, 1993, 2000], University of Colima Bulletin. 0 : Lateral activity (Volcancito 1869-1873). Dashed line: no data.

\section{Eruptive history}

The 430-year historical records of CV show that it is a very active volcano, with a cyclic behaviour that ends in Vulcanian and Plinian eruptions approximately every 100 years. The first eruptive analyses were carried out by Bárcena [1887] and Starr and Arreola [1903], who reported that CV has effusive and explosive periods between resting intervals, and that the intensity and magnitude of the eruptions had increased with time. Waitz [1932] considered that CV has a cyclic behaviour, and later studies by Luhr and Carmichael [1982], Martin Del Pozzo and Romero [1988] and Robin et al. [1991] have also confirmed eruption cycles in the recent activity of CV. These studies have proposed four historic cycles, each of which began with slow lava ascent, continued intermittently with lava or pyroclastic eruptions, and ended in explosive eruptions with pyroclastic flows and extensive ash-fall, which clears the crater for a new cycle. Luhr and Carmichael [1990] associated compositional variations with the cycles, which have mostly involved basic andesitic magmas in the second and third cycles (1690-1818, 1818-1913), which ended in explosive eruptions. Luhr and Carmichael [1990] also considered that the 1913 eruption had more hydrous andesitic magma than that in 1818 (basic andesitic magma), because of the presence of hornblende.

We present here the results of a new historical analysis. Each cycle ends in a VEI 4 Plinian eruption (Figure 2). For decades, lava ascends until it reaches the crater and a dome is formed. Afterwards, Merapi flows and hot avalanche deposits are generated by lava flow gravitational collapse, or from dome growth on a steep slope. The Vulcanian eruptions grow stronger and more frequent, producing ashfall and pyroclastic flows, and a new Plinian eruption eventually expels the dome, producing ash-fall up to distances of more than $700 \mathrm{~km}$ from $\mathrm{CV}$, and forming block and ash flows up to $15 \mathrm{~km}$ away [Saucedo et al. 2010].

\section{Cycle I (?-1611)}

Early records refer to eruptions with tephra and pyroclastic flows (Figure 2). An eruption in 1576 involved ash-fall and pyroclastic flows and coincided with the death of many young people, although these deaths might have been associated with an epidemic that broke out in the same year and that killed more than half of the populations of 22 villages in Colima [Tello 1651, Perez de Leon 1789]. The following eruptions in 1585, 1587, 1589, 1590, 1602, 1606 and 1611 produced important lapilli, scoria and ash-falls, but the main impact of the stronger eruptions in 1576 and 1611 was on livestock and agriculture, in addition to the constant fear of the population [Tello 1651, Mota Padilla 1742, Bárcena 1887, Ciudad del Real 1976, Breton et al. 2002].

\section{Cycle II (1611-1690)}

Another eruption in 1623 was attributed to CV, but information regarding this event is limited, and therefore the characteristics of the eruption are not known [Tello 1651, Vizcarra 1891]. It was not until 1690 that another explosive eruption was reported, of a Pelean type, with strong seismic activity [Medina 1983]. Martin Del Pozzo and Romero [1988] considered this as the end of the second cycle.

\section{Cycle III (1690-1818)}

CV produced ash in 1744, 1749 and 1750, which fell on the city of Colima [Barcena 1887, Arreola 1915]. In 1769, lava flows were reported, and in 1770 there was an explosion that was preceded by tremors and loud noises, and which formed a dense ash column and pyroclastic flows. Ash fell on Guadalajara for 3 days, and the pyroclastic flows filled the La Joya ravine on the southwest, covering plants, cattle, birds and other animals [Perez de Leon 1789]. The ash-fall resulted in darkness in the surrounding areas, which reached the city of Durango, $550 \mathrm{~km}$ north of CV [Perez de Leon 1789]. Due to the extent of the ash-fall and the 3-hour duration of the eruption, it appears to have been a VEI 3 event. CV continued to be active in 1771, 1780 and 1794-1795. Lava flows, rockslides, ash emission, and fumarolic activity were recorded in 1804, 1806 to 1809 , and 1811 [Barcena 1887, Arreola 1915].

At the beginning of 1818 , the crater was filled by a 
dome, and on February 15, 1818, it was destroyed by an eruption that started with an explosion that was heard in the cities of Ciudad Guzman and Leon, $26 \mathrm{~km}$ and $275 \mathrm{~km}$ from CV, respectively [Waitz 1932]. The tephra cloud «covered the moon» and produced darkness [Arreola 1915, Waitz 1932]; a loud noise was heard two hours later (22:00 hours). The pyroclastic flows coming down the Muerto ravine on the southern side of the volcano were seen by the inhabitants of San Marcos. These flows destroyed the forests and killed cattle, while lapilli and ash fell to the east-northeast, mostly between 20:00 and 22:00 hours [Arreola 1915, Waitz 1932]. The ash caused damage to the roofs of the houses in Ciudad Guzman, and some collapsed because of the weight. Distal ash arrived as far as Guadalajara $(140 \mathrm{~km})$, Leon $(275 \mathrm{~km})$, Guanajuato $(310 \mathrm{~km})$, Zacatecas $(384 \mathrm{~km})$, San Luis Potosi $(425 \mathrm{~km})$, Querétaro $(345 \mathrm{~km})$ and Mexico City $(470 \mathrm{~km})$. This 1818 eruption, which left an irregular funnel-shaped crater, was short and was followed by steam emissions and some earthquakes in later years [Vizcarra 1891, Waitz 1932].

\section{Cycle IV (1818-1913)}

Lava ascended from a depth of $300 \mathrm{~m}$ to $200 \mathrm{~m}$ between 1834 and 1866, and in 1869, a lateral dome known as "Volcancito" was formed on the upper north-eastern side of the volcano, activity that continued until 1873 [Barcena 1887]. In 1869, a tremor was felt in San Marcos and San Gabriel, which preceded lava flows, ballistics and ash emission, and which scared the population [Arreola 1915]. Fumarolic activity with sporadic ash emission and underground noises were reported from the central crater in 1869,1872 to 1874,1877 and 1879 [Bàrcena 1887, Arreola 1915, García-Acosta and Suárez 1996].

At the end of 1880, a central dome overflowed the crater edge, which produced several lava flows, as well as ash emission, in 1880-1881, 1885-1886, and 1889-1890 [Arreola 1915, Waitz 1932]. The crater was then filled again by a summit dome, but explosions in 1903 and 1908 produced pits in this [Starr and Arreola 1903, Diaz 1906, Waitz 1932].

The 1913 eruption began with loud noises and thunder, between January 17 and 18 , forcing the people $7 \mathrm{~km}$ to the east of the volcano to abandon their farms on the higher parts of CV and to take refuge on the plateau, which is today Juan Barragan [Waitz 1932]. On January 18, ash-fall and constant noise were reported; the 1880 dome was totally destroyed on January 20. At dawn on January 20, a series of explosions formed dense ash columns that were accompanied by loud noise, which lasted from 15:00 to 16:00 hours. After 16:00 hours, surges and block and ash flows descended $\sim 15 \mathrm{~km}$ from the crater, which filled the ravines by up to $40 \mathrm{~m}$ [Waitz 1932]. The flows caused fires and killed cattle. These flows were remobilized as hot lahars during the rainy season several months later, killing eight people and a lot of cattle [Waitz 1932, Saucedo 1997]. Ash fell to the north- northeast as far as $725 \mathrm{~km}$ from CV [Waitz 1932]. The 10-15$\mathrm{cm}$-thick ash and pumice fall in Ciudad Guzman caused roof collapses, and $0.5 \mathrm{~cm}$ of ash fell on Guadalajara, and $0.01 \mathrm{~cm}$ on Zacatecas, Aguascalientes and Saltillo [Waitz 1932]. The 1913 eruption left a 400-m-diameter crater with irregular peaks on the edges [Waitz 1932].

During the 1913 eruption, the main direction of the ash plume was to the north-northeast, although people in the city of Colima $30 \mathrm{~km}$ to the south also mentioned darkness and that their candles blew out due to the ash in the air [Navarro, personal communication].

\section{Cycle V (1913-?)}

Lava was observed at a depth of $50 \mathrm{~m}$ in the crater in 1922, while in 1940, it had ascended nearly to summit level [Waitz 1932, Mooser 1961]. In 1957, loud noises were heard, followed by steam emission, which scared the local population. After 1958, the dome grew by $70 \mathrm{~m}$ in one year [Mooser 1961, Vizcaino 1993]. Between 1961-1962 andesitic lava flows from the dome advanced $20 \mathrm{~cm} / \mathrm{d}$, reaching $1 \mathrm{~km}$ to the north, northeast and northwest of the crater [Mooser 1961]. In 1970, noises and local seismicity preceded small ash emissions [Vizcaino 1993]. Between 1975 and 1976, the volcano produced local ash-fall, two lava flows $>3.5 \mathrm{~km}$ long and $50 \mathrm{~m}$ thick, and block and ash flows 4.5 $\mathrm{km}$ long that caused fires on the south-eastern part of CV [Thorpe et al. 1977].

During 1981, there was fumarolic activity and ash-fall in the summit area, and in early 1982, lava flowed $1 \mathrm{~km}$ southwestward. In 1986, an ash cloud was seen from the city of Colima, and in 1987, an explosion produced a pit of $100 \mathrm{~m}$ to $150 \mathrm{~m}$ in diameter and $30 \mathrm{~m}$ to $40 \mathrm{~m}$ deep on the upper eastern flank of CV [Flores 1987]. In 1988, fumarolic activity alternated with small explosions.

After increasing fumarolic and seismic activity and rockslides from the dome in 1991, a small new dome grew through the summit dome. Its growth caused partial collapse of the summit dome to the south, which produced pyroclastic flows and was followed by lava advance [Rodríguez-Elizarrarása et al. 1991, Gonzalez et al. 1993]. This dome was destroyed by an explosion in 1994, which produced a crater $135 \mathrm{~m}$ in diameter and $40 \mathrm{~m}$ deep [Reyes and De la Cruz 2002]. The eruption also produced ash-fall 15 $\mathrm{km}$ to the west, impact craters up to $2 \mathrm{~km}$ from the crater, and pyroclastic flows over $4 \mathrm{~km}$ long [Saucedo 1997].

During 1997, the seismic crises and rockslides from the dome decreased after explosions [Martin Del Pozzo et al. 2002], but in November 1998, the seismicity and rockslides increased, which ended with lava extrusion from the dome. On November 18, 1998, growth of a new dome and an increase in seismicity caused the authorities to evacuate the population of La Yerbabuena and Juan Barragan, $10 \mathrm{~km}$ and $7 \mathrm{~km}$ from the crater. On November 21, 1998, new lava flow 
was accompanied by Merapi flows; lava continued flowing until the end of November, when collapse of the lava front formed block and ash flows that reached $4.8 \mathrm{~km}$ in the Cordoban ravine [Navarro et al. 2002, Saucedo et al. 2002].

In February 1999, the seismicity increased, and it ended with an explosion that destroyed part of the new dome. The noise was heard in Ciudad Guzman and Colima, while the ash column that was $3 \mathrm{~km}$ to $4 \mathrm{~km}$ high moved to the east and south of the volcano [Breton et al. 2002]. Ballistics reached between $3.5 \mathrm{~km}$ and $4 \mathrm{~km}$ on the north and northeast, which formed impact craters that were more than $2 \mathrm{~m}$ in diameter. The activity continued, and on May 10, 1999, another explosion was heard in Colima, which formed an ash column $6.5 \mathrm{~km}$ high and pyroclastic flows down La Lumbre and El Cordoban, and produced ballistics up to 4.5 $\mathrm{km}$ away that caused fires on the upper parts of CV. On July 17, 1999, after 13 hours of seismicity, an eruption formed a $10-\mathrm{km}$-high ash plume that produced ash-fall on Zapotitlan de Vadillo, $21 \mathrm{~km}$ west of $\mathrm{CV}$; block and ash flows ran down the ravines $3.3 \mathrm{~km}$ towards the south and southwest, which buried the vegetation and covered the 1998 lava flow [Saucedo et al. 2002, Macias et al. 2006]. The explosion produced a crater with a diameter of $230 \mathrm{~m}$ and a depth of $70 \mathrm{~m}$ to $80 \mathrm{~m}$. On July 18,1999 , the pyroclastic flows were remobilized as hot lahars, which followed the same southsouthwest path [Breton et al. 2002]. Small explosions and low seismicity continued for several months [Breton et al. 2002].

During 2000, lava flowed down the Beltran, Durazno and Cafecito ravines on the southeast side of the volcano, with accompanying Merapi flows. During the rainy season, these were remobilized as lahars, and they damaged the bridge over the state highway, which isolated the communities of San Jose del Carmen and La Becerrera [http:/ / www.ucol.mx]. In 2001, another eruption produced block and ash flows towards the southwest, and ash-fall on San Marcos and Tonila, as well as new impact craters to the north of CV [GVN 2001]. During May 2001, the formation of a new dome was reported, and a spine on the dome was observed in December 2001 [GVN 2001]. In January 2002, the dome growth continued. In February 2002, lava flowed southwards, followed by pyroclastic flows [Smithsonian Institution 2000]. From March to May 2002, there was frequent sliding from the front of the lava flows, so the authorities evacuated several towns to the southwest and southeast of CV from May 18 to June 3, 2002. Lava extrusion continued until February 2003, and in July and August 2003, eruptions produced block and ash flows and 3$\mathrm{km}$-high ash plumes that travelled to the southwest and northwest, and ash fell on the town of El Grullo at $\sim 60 \mathrm{~km}$ to the northwest of CV [Smithsonian Institution 2003]. The eruption was noisy due to rocks tumbling down the slopes. There were several small ash emissions until December 2003, when an eruption produced ash-fall in Ciudad
Guzmán, and ballistics [Smithsonian Institution 2003]. In September 2004, a dome started growing, which produced 2-km-long block and ash flows, followed by lava flows to the north and west-northwest that reached $1.8 \mathrm{~km}$ and $0.6 \mathrm{~km}$ in October 2004 [http://www.ucol.mx]. During 2005, eight pyroclastic flows with ash plumes from $2 \mathrm{~km}$ to $8.5 \mathrm{~km}$ above the crater were produced by Vulcanian eruptions. In September 2005, pyroclastic flows were remobilized as lahars, which reached the power lines in Montegrande. The explosions decreased in 2006, although vapour emissions and small ash columns were still produced [G. Reyes, personal communication].

Since February 2007, a new dome has started to grow, and this now exceeds the crater rim. Dome growth still continues, with small emissions [http://www.colimaestado.gob.mx/seguridad]. Given the recurrence interval of Plinian events and the similarities between the present activity and the activity that preceded the 1818 and 1913 eruptions, it has become necessary to evaluate the distribution, thickness and effects that the ash would have in the future.

\section{Wind distribution}

The dispersion of volcanic ash is controlled mainly by wind transport, and meteorological data of wind direction and speed have been used to identify the patterns of tephra dispersal at Etna [Andronico et al. 2005], Popocatepetl [Delgado 2001, Martin Del Pozzo et al. 2008], CV [Navarro et al. 2003], Auckland Volcanic Field [Houghton et al. 2006] and Nevado de Toluca [Aceves et al. 2007], among others.

In the present study, we proposed a detailed wind study per month because Plinian eruption plumes can encounter large variations in horizontal wind speeds. At CV, the vertical wind distribution was divided in four altitudinal levels that were based on wind direction and speed. The wind data was grouped as January to March, June to August, and November and December, because of similar directions, and data from April, May, September and October were included.

The dominant wind direction at level I (4,000-9,000 m a.s.l.) is westerly-south-westerly from January to May and from November to December. At this level, from June to September, easterly winds prevail, while during October, the trade winds are very unstable, so the wind can blow in any direction, with a maximum speed of $100 \mathrm{~km} / \mathrm{h}$. Figure 3 shows the wind directions for each level according to the month of the year.

At level II (9,000-14,000 $\mathrm{m}$ a.s.1.), the dominant wind direction is westerly-south-westerly from January to March and from October to December. In April and May, the dominant wind is westerly, while from June to September, the wind direction is variable. At level II, the greatest wind velocity is $150 \mathrm{~km} / \mathrm{h}$ from January to May, and $100 \mathrm{~km} / \mathrm{h}$ from June to December. 


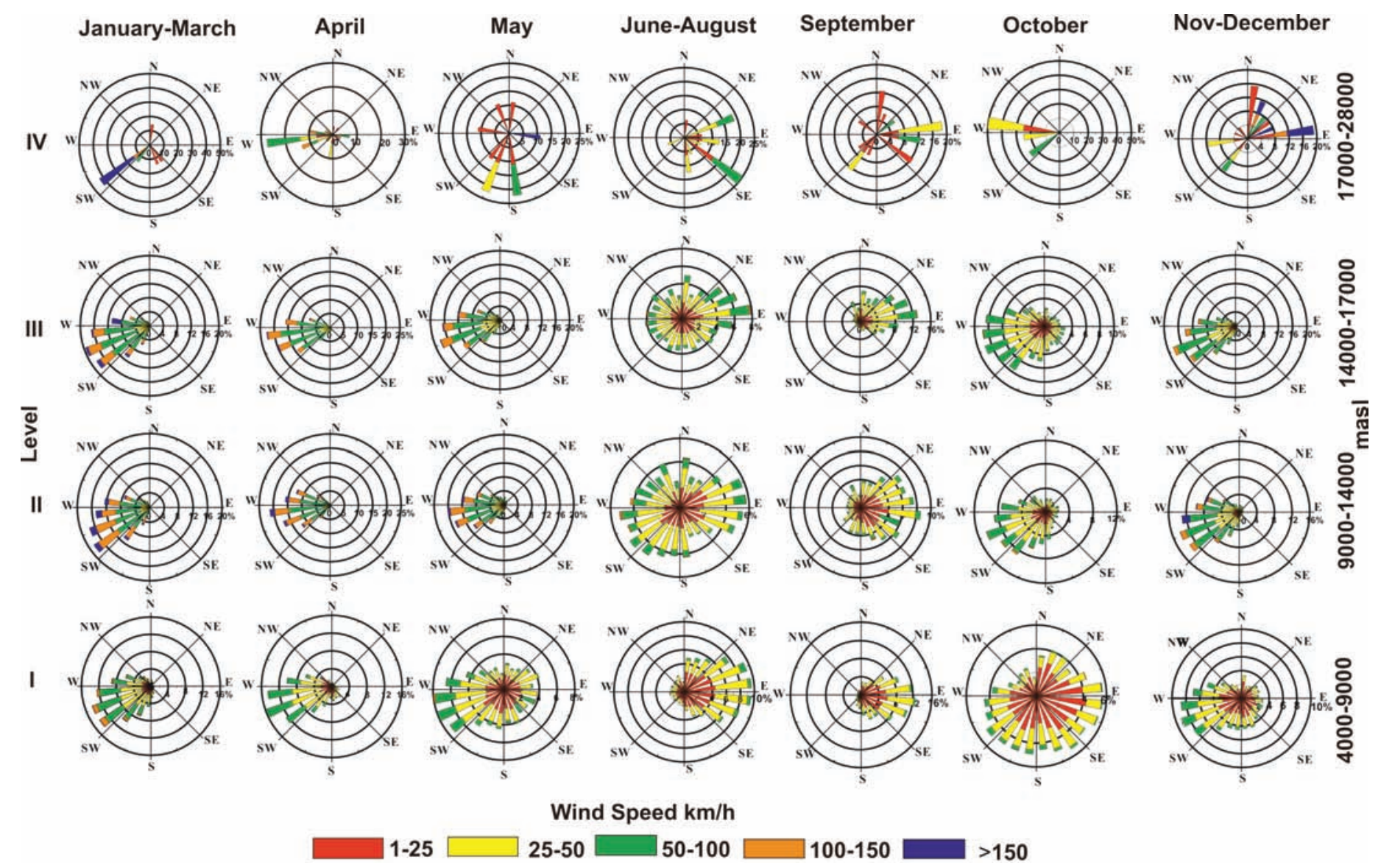

Figure 3. Monthly wind directions for altitudinal levels, based on radiosonde data (1990-2005) from the Manzanillo Station. Wind direction frequency diagrams showing average percentage of time that winds blow towards sectors centered on 4 sectors.

The winds at level III (14,000-17,000 $\mathrm{m}$ a.s.l.) are similar to those at level II: the dominant winds are west-southwesterly from January to May and from October to December, while there are easterly winds with secondary directions from June to September. At this level, the maximum wind speed is more than $150 \mathrm{~km} / \mathrm{h}$ from January to May and in November and December, and $100 \mathrm{~km} / \mathrm{h}$ from June to October.

At level IV (17,000-28,000 $\mathrm{m}$ a.s.l.), the wind data was divided into six groups according to similar wind directions in several months: January to March; April and October; May; June to August; September; and November and December. At this level, south-westerly winds prevail from January to March, and westerly in April and October. During May, south-south-westerly and south-south-easterly winds dominate, from June to August, south-easterly winds prevail, while in September and in November and December, the easterly winds fluctuate. The maximum wind speed is 150 $\mathrm{km} / \mathrm{h}$ from January to March and in November and December, with $100 \mathrm{~km} / \mathrm{h}$ from April to August, and 50 $\mathrm{km} / \mathrm{h}$ in September and October. This level is associated with the very fast winds (the jet stream).

In a Plinian eruption, ash plumes can reach the stratosphere (between $16 \mathrm{~km}$ and $30 \mathrm{~km}$ high), which would allow for higher and wider ash dispersion. The Plinian column height in the 1913 eruption was estimated at $23 \mathrm{~km}$
[Saucedo et al. 2010]. Here we have thus integrated the wind distribution at level IV (from 17,000-28,000 $\mathrm{m}$ a.s.1.) and estimated the ash dispersion for a similar event to that of 1913. The dominant wind course, as the greatest frequency per month, for level IV was used to establish the scenarios that would result from a Plinian eruption.

\section{Ash-fall scenarios}

Many theoretical and experimental models have been developed from the buoyant plume theory, as modified for volcanic eruptions [Wilson et al. 1978, Carey and Sparks 1986]. Similarly, many studies have applied semi-analytical and numerical models for the transport and deposition of volcanic ash based on vulcanological parameters, such as: total mass, column height, column shape coefficient, grain size, mass eruption rate, and daily wind profile per season [Folch and Felpeto 2005, Macedonio et al. 2008, Costa et al. 2009, Selva et al. 2010]. These studies have proposed hazard maps for ash-fall at Vesuvius and Campi Flegrei. The 1913 CV eruption was shorter than the 1979 Vesuvius eruption, although the column height and mass was similar (Table 3). The scenario constructions for CV are here based on ash-fall depths, and take into account the isopach thickness from the 1913 Plinian eruption (Table 4), the dominant wind direction, the total number of people, and the main economic activities, land use and communications infrastructures. 


\begin{tabular}{|c|c|c|c|c|c|c|}
\hline Volcano & $\begin{array}{l}\text { Eruption } \\
\text { Date }\end{array}$ & $\begin{array}{c}\text { Total mass } \\
(\mathbf{k g})\end{array}$ & $\begin{array}{c}\text { Volume } \\
\left(\mathrm{km}^{3}\right)\end{array}$ & $\begin{array}{c}\text { Column } \\
\text { Height (km) }\end{array}$ & $\begin{array}{c}\text { Duration } \\
\text { (h) }\end{array}$ & References \\
\hline & & & & & & $\begin{array}{l}\text { Sigurdsson et al.1985 } \\
\text { Pfeiffer et al. } 2005\end{array}$ \\
\hline Vesuvius, Italy & $79 A D$ & $2 \times 10^{12}$ & & 27 & 18 & Macedonio et al. 2008 \\
\hline Colima, Mexico & $1913-01-20$ & $1.5 \times 10^{12}$ & 1.4 & 23 & 4.6 & $\begin{array}{l}\text { Saucedo et al. } 2010 \\
\text { Carey and Sigurdsson, } 1989\end{array}$ \\
\hline St. Helens, US & $1980-05-18$ & & 0.3 & 19 & 9.1 & Carey et al. 2010 \\
\hline $\begin{array}{l}\text { Campi Flegrei, Italy } \\
\text { (Agnano Monte Spina) }\end{array}$ & $4.1 \mathrm{Ka}$ & $5.2 \times 10^{11}$ & 0.11 & 26 & & $\begin{array}{l}\text { De Vita et al. } 1999 \\
\text { Costa et al. } 2009\end{array}$ \\
\hline
\end{tabular}

Table 3. Main parameters of the 1913 eruption as compared to other Plinian eruptions.

\section{Scenario 1}

From January to March, the dominant wind direction is towards the northeast (Figure 4).

\section{$100 \mathrm{~cm}$}

More than $100 \mathrm{~cm}$ of tephra would cover areas up to a distance of $3 \mathrm{~km}$ (Figure 4). The Playon area on the northern part of CV and the north-eastern slope of the Nevado de Colima would be covered by ash and pumice. Mature pines would survive, as occurred in 1913, although their branches would break off due to the weight of the ash, and the small pine trees and holm oaks in the area would be buried. Many wild animals, such as pumas, mountain cats, ocelots and deer, and many types of birds, like hawks and humming birds, all of which are endangered species, would die. The thick ash-fall would also kill insects and reptiles. Ash abrasion on the insect epicuticular wax layer causes rapid desiccation and death [Cook et al. 1981]. Fires caused by ballistics would burn off the vegetation. The seismic station to the north of the crater would be destroyed.

\section{$50 \mathrm{~cm}$}

From $50 \mathrm{~cm}$ to $100 \mathrm{~cm}$ of ash would be expected between $3 \mathrm{~km}$ and $11 \mathrm{~km}$ from the crater on the northeastern quadrant of the Nevado de Colima National Park. This zone is covered by coniferous forests with natural grasslands, and it is a popular camping site. The ash would bury small trees and grass, and break off tree branches. The wild animals, and especially birds, would die. The seismic and visual monitoring equipment at the Nevado Volcano,

\begin{tabular}{ccc}
\hline $\begin{array}{c}\text { Isopach } \\
\text { Thickness } \mathbf{( c m )}\end{array}$ & $\begin{array}{c}\text { Distance from the } \\
\text { Volcano } \mathbf{( k m )}\end{array}$ & $\begin{array}{c}\text { Area } \\
\left.\mathbf{( k m}^{\mathbf{2}}\right)\end{array}$ \\
\hline 100.00 & 3 & 4.24 \\
50.00 & 11 & 15.46 \\
15.00 & 38 & 382 \\
$<1.00$ & 64 & 3643.78 \\
0.50 & 160 & 8717 \\
0.10 & 390 & $102,915.880$ \\
0.01 & 725 & $191,318.00$ \\
\hline
\end{tabular}

Saucedo et al. 2010; Fonseca 2003. See figure 1

Table 4. Depth ranges of the ash-fall of the 1913 Plinian eruption. which is $5.3 \mathrm{~km}$ from the $\mathrm{CV}$ crater, and the radio and television microwave station on the northern flank of the Nevado Volcano would be destroyed.

\section{$15 \mathrm{~cm}$}

With $15 \mathrm{~cm}$ to $50 \mathrm{~cm}$ of ash, lapilli and pumice fall, areas northeast of $\mathrm{CV}$, between $11 \mathrm{~km}$ and $38 \mathrm{~km}$ from the $\mathrm{CV}$ crater would be affected (Table 5 ). In this area, there are more than 100,000 inhabitants who would be subject to stress and corneal abrasion, as well as irritation of the eyes, skin, nose, scalp and respiratory system, due to the ash [Horwell and Baxter 2006, Nieto et al. 2007]. Agriculture, cattle ranching, and trade and tourism would be affected (Table 5). The ash-fall would bury crops and cause defoliation of fruit trees, which would result in seasonal crop loss and a higher percentage of deformed fruit. Livestock would get sick and/or die after consuming contaminated grass and water. It would be difficult for the animals to find food and water sources. In the 1818 and 1913 eruptions of $\mathrm{CV}$, ash also caused roof collapses, while in Ciudad Guzman, several cows died after drinking polluted water and eating on pastures with ash [Waitz 1932].

The Juan Barragan and Ejido Atenquique springs supply drinking water to local people. Water ducts and pumps would be affected by ash abrasion, and the system would get blocked or destroyed, as happened in Ciudad Guzman in the 1913 eruption. There are radio and television microwave stations on the north-eastern flank of CV, power substations in Ciudad Guzman, and power lines that supply electricity to the Guadalajara metropolitan area. The ash would cause transmission problems, due to interference and cable and plate abrasion. The alarm system for lahars in Juan Barragan and Atenquique would be damaged too.

The unpaved roads that lead to Juan Barragan and Ejido Atenquique would be blocked by ash and fallen trees, and the main roads (Colima-Guadalajara) would also be paralyzed due to blockage, lack of visibility, and damage to the oil, fuel and air filters of vehicles. This would limit the effective response of the emergency services. The 1770, 1818 and 1913 eruptions caused darkness in the area, and in the May 18, 1980, eruption of Mount St. Helens, many thousands of kilometers of country roads, municipal streets and irrigation district service roads were closed for weeks [Schuster 1982]. 

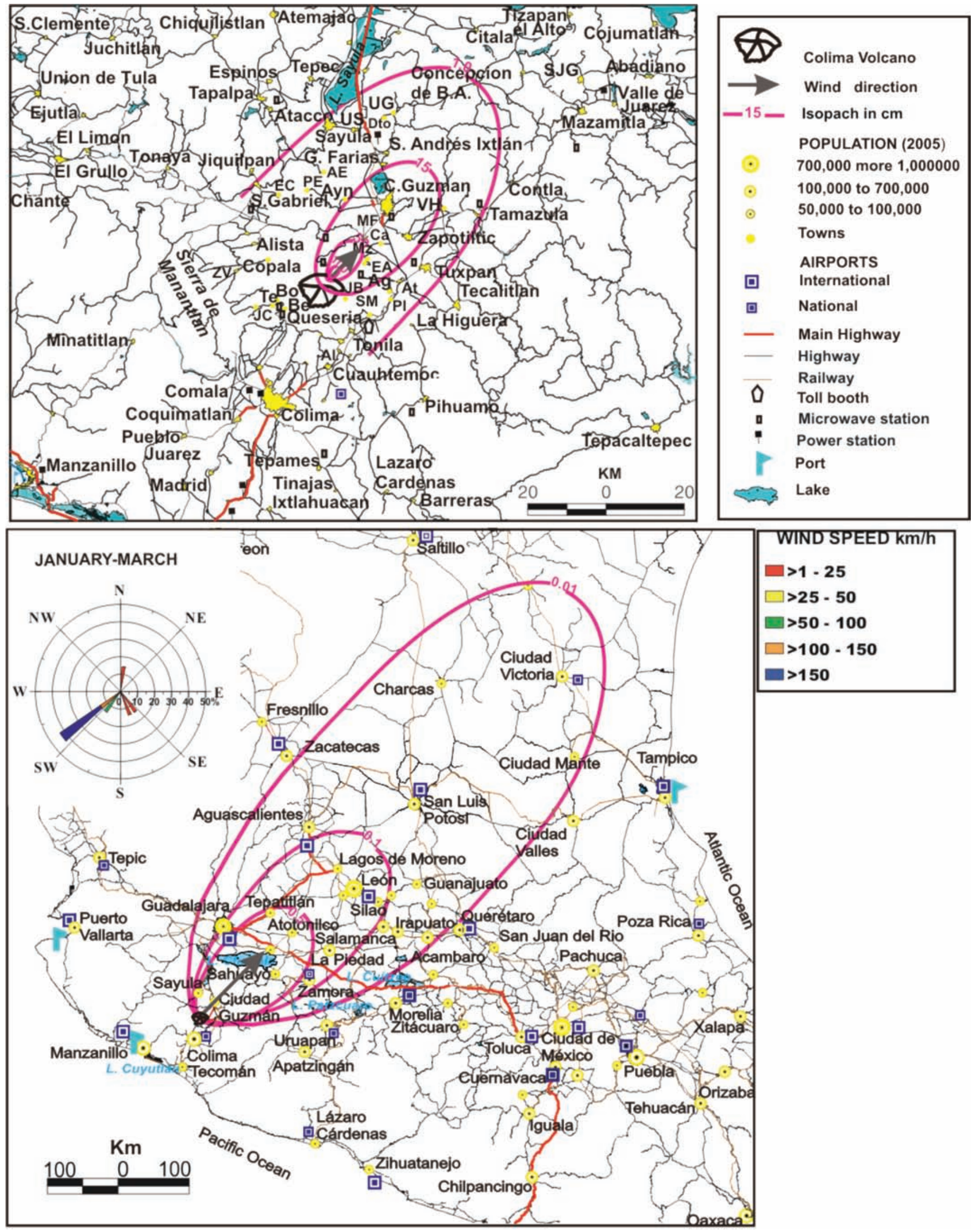

Figure 4. Scenario 1. For an eruption from January to March, showing the northeast area that would be affected by a future Plinian eruption. Two scales shown according to isopach contours: top, $>1 \mathrm{~cm}$; bottom, $0.01 \mathrm{~cm}$ to $0.5 \mathrm{~cm}$. The maps show the main cities, populations and airports. Towns: (Pl) El Platanar; (Bo) El Borbollon; (Be) La Becerrera; (JB) Juan Barragan; (Ag) El Agosto; (Ma) San Marcos; (Te) El Tecuan; (At) Atenquique; (EA) Ejido Atenquique; (Mz) Los Mazos; (Ca) Las Canoas; (MF) La Mesa y el Fresnito; (Al) Alcaraces; (ZV) Zapotitlán de Vadillo; (Dto) El Destacamento; (PE) Los Pozos y el Ocote; (VH) Vista Hermosa; (SJG) San José de Gracia; (LB) Loma Blanca; (AE) Agua Escondida; (EC) El Carpintero; (Ayn) Atequizayán; (US) Usmajac. Inset: wind diagram showing frequency in percentage and wind speed in $\mathrm{km} / \mathrm{h}$. 


\begin{tabular}{|c|c|c|c|c|}
\hline $\begin{array}{l}\text { Ash } \\
\text { thickness } \\
\text { (cm) } \\
\end{array}$ & Localities & $\begin{array}{l}\text { Population } \\
(2005)\end{array}$ & $\begin{array}{l}\text { Main economic Activities in each } \\
\text { isopach unit }\end{array}$ & Main Roads \\
\hline 15 & $\begin{array}{l}\text { Las Canoas } \\
\text { Ciudad Guzman } \\
\text { Ejido Atenquique } \\
\text { Juan Barragan } \\
\text { La Mesa y El Fresnito } \\
\text { Los Mazos } \\
\text { Zapotiltic }\end{array}$ & $\begin{array}{l}140 \\
93,609 \\
100 \\
60 \\
900 \\
90 \\
21,440\end{array}$ & $\begin{array}{l}\text { Farming: peach, pomegranate } \\
\text { guava, agave, sugar cane, corn } \\
\text { pigs and poultry } \\
\text { Cattle ranching } \\
\text { Trade } \\
\text { Tourism } \\
\text { Industry: cement }\end{array}$ & Colima-Guadalajara \\
\hline$>1.0$ & $\begin{array}{l}\text { Atenquique } \\
\text { Queseria } \\
\text { San Gabriel } \\
\text { San Marcos } \\
\text { Sayula } \\
\text { Tamazula } \\
\text { Tonila } \\
\text { Tuxpan }\end{array}$ & $\begin{array}{l}849 \\
8,079 \\
4,190 \\
3,179 \\
27,311 \\
17,441 \\
3,099 \\
26,134\end{array}$ & $\begin{array}{l}\text { Farming: sugar cane, corn } \\
\text { vegetables, legumes, coffee, lemon, } \\
\text { forage grass, pigs and poultry } \\
\text { Ranching: cattle } \\
\text { Industry: lumber and paper }\end{array}$ & $\begin{array}{l}\text { Colima-Guadalajara } \\
\text { Tuxpan-Mazamitla }\end{array}$ \\
\hline 0.5 & $\begin{array}{l}\text { Guadalajara } \\
\text { Atotonilco el Alto } \\
\text { Poncitlan }\end{array}$ & $\begin{array}{l}4,295,853 \\
26,044 \\
13,105\end{array}$ & $\begin{array}{l}\text { Industry: food, pharmaceutical } \\
\text { electronics, shoe, textile and lumber } \\
\text { Tourism } \\
\text { Trade } \\
\text { Farming: corn, vegetables, } \\
\text { sugar cane, pigs, goat and poultry } \\
\text { Ranching: cattle, horse and sheep }\end{array}$ & $\begin{array}{l}\text { Colima-Guadalajara } \\
\text { León-Morelia-Mexico }\end{array}$ \\
\hline 0.1 & $\begin{array}{l}\text { Leon } \\
\text { Zamora } \\
\text { Lagos de Moreno }\end{array}$ & $\begin{array}{l}1,278,087 \\
127,606 \\
92,712\end{array}$ & $\begin{array}{l}\text { Industry: Shoe, leather and } \\
\text { and petrochemical } \\
\text { Trade } \\
\text { Farming: corn, vegetables, } \\
\text { sugar cane, pigs, goat and poultry } \\
\text { Ranching: cattle, horse and sheep }\end{array}$ & Panamerican highway \\
\hline 0.01 & $\begin{array}{l}\text { San Luis Potosí } \\
\text { Aguascalientes } \\
\text { Irapuato } \\
\text { Celaya } \\
\text { Ciudad Victoria } \\
\text { Salamanca } \\
\text { Ciudad Mante } \\
\text { Guanajuato } \\
\text { Charcas }\end{array}$ & $\begin{array}{l}685,934 \\
663,671 \\
342,561 \\
310,413 \\
278,455 \\
223,623 \\
112,061 \\
70,798 \\
20,173\end{array}$ & $\begin{array}{l}\text { Industry: shoe, leather and } \\
\text { petrochemical } \\
\text { Trade } \\
\text { Tourism } \\
\text { Farming: corn, vegetables, pigs } \\
\text { goat and poultry } \\
\text { Ranching: cattle, horse and sheep }\end{array}$ & Panamerican highway \\
\hline
\end{tabular}

Table 5. Scenario 1. Localities, populations, main economic activities and roads which would be affected by different ash-fall levels during an eruption occurring from January to March.

The Zapotlan Lagoon is located $30 \mathrm{~km}$ northeast of CV. This is a wetland of international importance, where the aquatic plants, migratory birds, insects and fish would be at risk. The ash would cause changes in the water $\mathrm{pH}$ and a decreasing food supply; some fish are very susceptible to water changes and would die or get scale disease.

\section{$>1 \mathrm{~cm}$}

From $1 \mathrm{~cm}$ to $15 \mathrm{~cm}$ of ash would be expected between $38 \mathrm{~km}$ and $64 \mathrm{~km}$ from CV. There are 70,000 people who live in this area. The ash would cause eye, skin and nasal irritation, and respiratory problems. Farming and cattle ranching would also be affected. Crops would be destroyed by being buried, and even more mature plants would suffer severely from the ash. Cattle would get sick or die through ingestion of contaminated pastures and water. Ash-fall would damage chimneys and roofs of the sugar mill in Queseria and the paper mill in Atenquique.

The Colima-Guadalajara and Tuxpan-Mazamitla highways have constant traffic, which would be affected by lack of visibility and ash accumulation, which would produce traffic jams for hours, or even for several days. The power stations in Sayula and Tamazula supply electricity to the region. Lightning and ash abrasion would damage the fuses in substations and would cause power shortages and blackouts.

\section{$0.5 \mathrm{~cm}$}

From $0.5 \mathrm{~cm}$ to $1 \mathrm{~cm}$ of ash-fall would be expected between $64 \mathrm{~km}$ and $160 \mathrm{~km}$ from CV. This area includes the more than 4 million people who live in the metropolitan area of Guadalajara and in small towns (Table 5). The effects in the future would be greater than in 1913 because of the higher population density. The roofs would have to be cleaned due to ash, and economic activities would be affected temporarily by lack of services and road access (Table 5). Corn and vegetable crops in the early stages of growth would be damaged by the ash, and livestock would get sick by eating pasture with ash.

Guadalajara is the second largest city in Mexico and has 
one of the busiest international airports, which handles 136,000 flights/year. The ash cloud would force the airport to close operations for hours or days, and would result in the deviation of air routes. The ash accumulation on airport runways, taxiways and aprons would need to be cleaned. In 1990, the ash from the Redoubt Volcano (Alaska) remained in the atmosphere and in the flight paths of many aeroplanes, which caused the Anchorage Kenai Airport, located $80 \mathrm{~km}$ from the volcano, to remain closed for several days [Casadevall 1994].

The main highways in the Colima area connect important cities, such as Guadalajara, Manzanillo, Ciudad Guzman, León, Morelia and Mexico City. The lack of visibility due to ash-fall would cause problems with traffic. The power stations in Guadalajara and Atotonilco supply electricity to over one million users. The towers and cables would be damaged by ash, causing power shortages and blackouts or power interruptions to homes, industries, shops and administrative services for hours or days. The alarm system for lahars in San Marcos would be damaged.

Chapala is the largest lake in Mexico, and it is a habitat for several species of migratory birds, such as the white pelican, as well as native plants and animals. This region has conservation programs to maintain the natural habitats of the lake, but ash-fall would produce serious contamination of the lake and modify the $\mathrm{pH}$ and nutrient conditions. Ashfall would also hinder the flight of birds.

\section{$0.1 \mathrm{~cm}$}

From $0.1 \mathrm{~cm}$ to $0.5 \mathrm{~cm}$ of ash would be expected between $160 \mathrm{~km}$ and $390 \mathrm{~km}$ from the CV crater. In this area, there are more than 1 million inhabitants. There would be respiratory problems because of the ash, although the effects on industry and trade would be minimal. The ash would have positive effects on some agricultural areas, because small amounts can act as natural fertilizers, but with cattle it would cause diarrhea and weight loss, and reduced meat and milk production [Fonseca et al. 2007].

The city of Leon has an international airport with 27,206 flights/year. The ash would force the airport to interrupt operations for hours due to ash in the air routes. In this area, the Panamerican highway that connects México City, Morelia, Querétaro, Irapuato and León would be affected. The main problem with the ash would be the traffic towards Guadalajara. The power stations in Leon and in Zamora would suffer damage to the transformers, which would cause blackouts.

\section{$0.01 \mathrm{~cm}$}

With $0.01 \mathrm{~cm}$ to $0.1 \mathrm{~cm}$ of ash-fall, this would reach between $390 \mathrm{~km}$ and $725 \mathrm{~km}$ from CV. In this area, there are more than 2 million inhabitants. The ash would have minimal effects on the economy of the area, because it would be incorporated into the soil in days, or even be carried away by the wind (Table 5).

The thermoelectric power stations in Salamanca and San Luis Potosi are important sources of income, as are the petrochemical and refinery industries in Salamanca. The ash would increase the pollution in the environment and cause skin and eye irritation as well as respiratory problems in the population.

The airports in Aguascalientes, San Luis Potosí and Ciudad Victoria handle between 11,506 and 23,071 international flights/year, while the airport in Celaya has 2,400 national flights/year. Fine ash would lead to flight cancellations due to ash in the air. The effects on the Panamerican highway and the power stations in San Luis Potosi and Saltillo would be minimal.

\section{Scenario 2}

The wind direction in April and October is eastwards (Figure 5). The area that would be affected is similar to that of the 1818 eruption, when ash fell in Ciudad Guzman, Guadalajara, Lagos de Moreno, Leon, Guanajuato, Zacatecas, San Luis Potosi, Querétaro and Mexico City [Arreola 1915, Waitz 1932].

\section{$100 \mathrm{~cm}$}

The coniferous forest (Mexican fir oyamel, cedar and pine) on the eastern flank of the Nevado de Colima would be covered by more than $100 \mathrm{~cm}$ of ash, lapilli and pumice, as in scenario 1 , and similar effects could be expected. Some mature trees could survive, but the small trees would be buried. Some animals would die due to asphyxia or desiccation. The fires caused by ballistics would burn off the vegetation.

\section{$50 \mathrm{~cm}$}

In the areas where $50 \mathrm{~cm}$ to $100 \mathrm{~cm}$ of ash would fall, the distribution would be similar to the $50 \mathrm{~cm}$ isopach in scenario 1 . The area is covered by coniferous forests with natural grasslands, which would be buried by ash, and the wildlife would die.

\section{$15 \mathrm{~cm}$}

From $15 \mathrm{~cm}$ to $50 \mathrm{~cm}$ of ash, lapilli and pumice would affect eastern areas between $11 \mathrm{~km}$ and $38 \mathrm{~km}$ from the CV crater. Over 20,000 people live in this area, mainly in small communities (Table 6). Effects similar to those of scenario 1 $(15 \mathrm{~cm})$ would expected. The ash would also cause roof collapses. The vegetables and agave crops would be buried (Table 6). Livestock would get sick and/or die, and it would cause a decline in meat, egg and milk production.

The Atenquique paper mill would be affected significantly by ash-fall, causing a decrease in the production of cellulose. Raw materials stored out in the open, as well as the chimneys and roofs, would be damaged by ash-fall. 

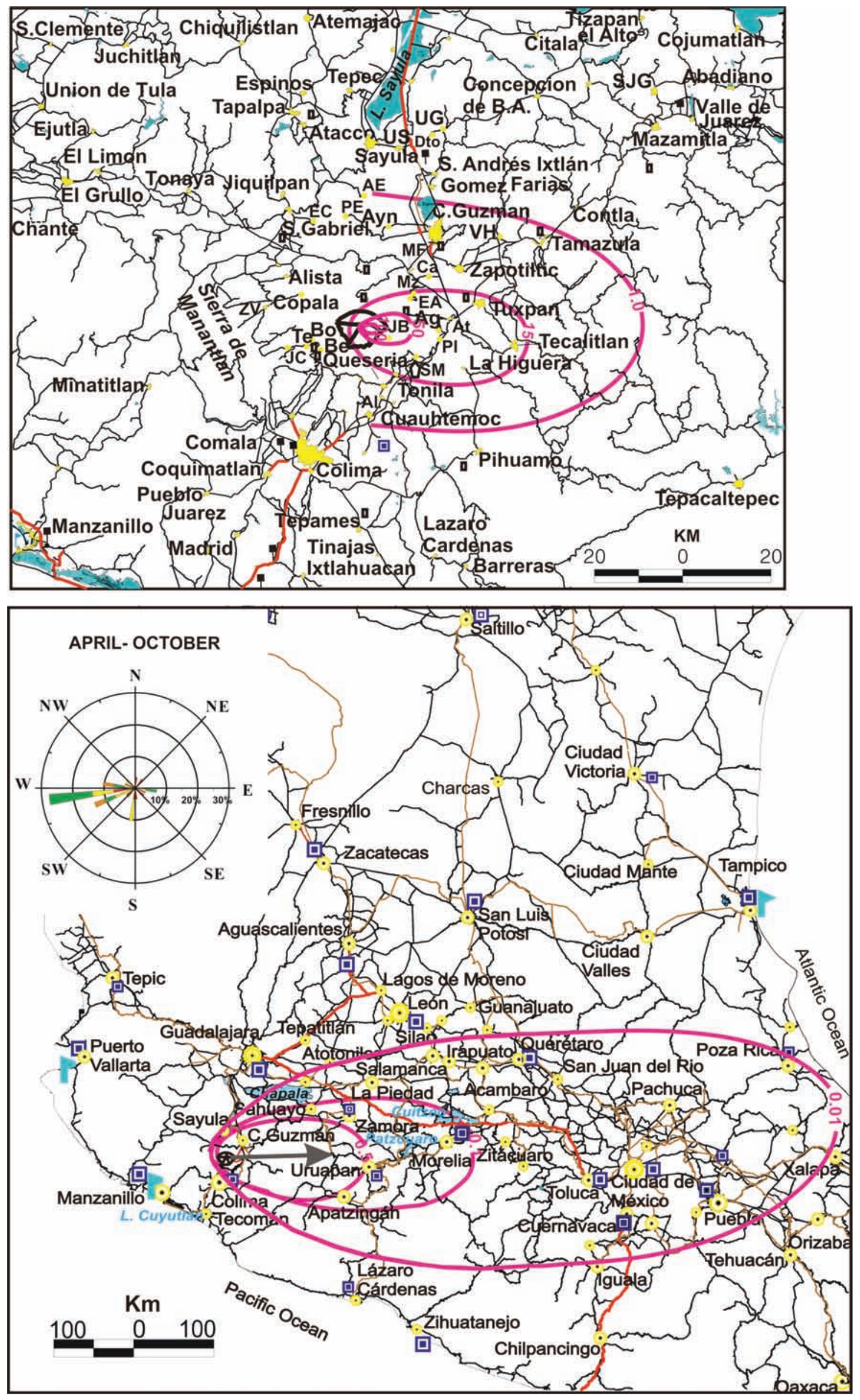

Figure 5. Scenario 2. For an eruption in April or October, showing the eastern area that would be affected by a future Plinian eruption. For details, see legend to Figure 4. 


\begin{tabular}{|c|c|c|c|c|}
\hline $\begin{array}{l}\text { Ash thickness } \\
(\mathrm{cm})\end{array}$ & Localities & $\begin{array}{l}\text { Population } \\
(2005)\end{array}$ & Main economic activities & Main Roads \\
\hline 15 & $\begin{array}{l}\text { Las Canoas } \\
\text { Ejido Atenquique } \\
\text { Los Mazos } \\
\text { Juan Barragan } \\
\text { El Agosto } \\
\text { El Platanar } \\
\text { Zapotiltic } \\
\text { Atenquique } \\
\text { Tuxpan }\end{array}$ & $\begin{array}{l}140 \\
100 \\
90 \\
60 \\
301 \\
452 \\
21,440 \\
849 \\
26,134\end{array}$ & $\begin{array}{l}\text { Farming: sugar cane, agave, } \\
\text { vegetables, corn, pigs and poultry } \\
\text { Ranching: cattle and sheep } \\
\text { Trade } \\
\text { Industry: lumber, paper and } \\
\text { cement }\end{array}$ & Guadalajara-Colima-Manzanillo \\
\hline$>1.0$ & $\begin{array}{l}\text { Gomez Farias } \\
\text { Vista Hermosa } \\
\text { Tamazula } \\
\text { Ciudad Guzman } \\
\text { La Mesa y El Fresnito } \\
\text { Tecalitlan } \\
\text { La Higera } \\
\text { San Marcos } \\
\text { Tonila } \\
\text { Queseria } \\
\text { Alcaraces } \\
\text { Cuauhtemoc }\end{array}$ & $\begin{array}{l}6,535 \\
413 \\
17,441 \\
93,609 \\
900 \\
12,053 \\
1,319 \\
3,179 \\
3,099 \\
8,079 \\
1,775 \\
8,165\end{array}$ & $\begin{array}{l}\text { Farming: sugar cane, corn } \\
\text { orchards, forage grass, pigs and } \\
\text { poultry } \\
\text { Ranching: cattle and goat } \\
\text { Trade } \\
\text { Tourism }\end{array}$ & Colima-Ciudad Guzman \\
\hline 0.5 & $\begin{array}{l}\text { Colima } \\
\text { Concepción BA } \\
\text { El Destacamento } \\
\text { Jiquilpan } \\
\text { Mazamitla } \\
\text { San Andres Ixtlan } \\
\text { Tapalpa } \\
\text { Tizapan el Alto } \\
\text { Union de Guadalupe } \\
\text { Sayula } \\
\text { Sahuayo } \\
\text { Uruapan } \\
\text { Zamora }\end{array}$ & $\begin{array}{l}294,828 \\
4,179 \\
163 \\
23,132 \\
7,096 \\
4,665 \\
16,057 \\
13,755 \\
873 \\
27,311 \\
59,316 \\
238,975 \\
230,777\end{array}$ & $\begin{array}{l}\text { Farming: corn, oats, beans, } \\
\text { sugar cane, tomatoes, pigs and } \\
\text { poultry } \\
\text { Ranching: cattle, sheep and goat } \\
\text { Trade } \\
\text { Tourism }\end{array}$ & $\begin{array}{l}\text { Guadalajara-Colima } \\
\text { Morelia-Lazaro Cardenas }\end{array}$ \\
\hline 0.1 & $\begin{array}{l}\text { Morelia } \\
\text { La Piedad } \\
\text { Apatzingan }\end{array}$ & $\begin{array}{l}735,624 \\
229,289 \\
93,180\end{array}$ & $\begin{array}{l}\text { Trade, Tourism } \\
\text { Tourism } \\
\text { Industry: construction and } \\
\text { manufacturing } \\
\text { Farming: corn, sorghum, poultry } \\
\text { pigs and rabbits } \\
\text { Ranching: cattle and sheep }\end{array}$ & Morelia-México \\
\hline 0.01 & $\begin{array}{l}\text { Ocotlán } \\
\text { Silao } \\
\text { Irapuato } \\
\text { Salamanca } \\
\text { Celaya } \\
\text { Zitácuaro } \\
\text { Querétaro } \\
\text { San Juan del Rio } \\
\text { Mexico City } \\
\text { Toluca } \\
\text { Puebla } \\
\text { Cuernavaca } \\
\text { Pachuca } \\
\text { Tula } \\
\text { Poza Rica }\end{array}$ & $\begin{array}{l}81,165 \\
66,483 \\
342,561 \\
143,838 \\
310,413 \\
78,821 \\
596,450 \\
120,984 \\
19,239,910 \\
1,633,052 \\
2,470,206 \\
802,371 \\
438,692 \\
28,432 \\
481,389\end{array}$ & $\begin{array}{l}\text { Industry: shoe, leather } \\
\text { and petrochemical } \\
\text { Trade } \\
\text { Tourism } \\
\text { Farming: corn, vegetables, pigs } \\
\text { and poultry } \\
\text { Ranching: cattle, horse and sheep }\end{array}$ & Salamanca-Morelia-Mexico \\
\hline
\end{tabular}

Table 6. Scenario 2. Localities, populations, main economic activities and roads which would be affected by different ash-fall levels during an eruption occurring from April and October.

Furthermore, silting of the river would be a threat in the rainy season, with the possible formation of lahars, and the alarm system for lahars in Juan Barragan, Atenquique and San Marcos would be damaged.

The main Guadalajara-Manzanillo highway connects western Mexico with the Pacific coast. The railroad line links the center of Mexico with the port of Manzanillo, and transports import and export goods. The roads and railroads would be blocked by ash.

The radio and television microwave stations on the northeast part of $\mathrm{CV}$ and in Tuxpan would have transmission problems due to interference and plate abrasion. Sayula, Tuxpan and Zapotiltic each have a power station, and power lines from Manzanillo supply power to Guadalajara; the ash would cause failures in electrical supplies and disruption of services. 


\section{$>1.0 \mathrm{~cm}$}

From $1 \mathrm{~cm}$ to $15 \mathrm{~cm}$ of ash would be expected between $38 \mathrm{~km}$ and $64 \mathrm{~km}$ from the CV crater. More than 130,000 people live in this area. The effects on the people and economic activities would be similar to scenario 1 with more than $1 \mathrm{~cm}$ of ash. The forage grass would be buried, and the cattle would get sick or die by eating contaminated pasture. Ash-fall would also damage chimneys and roofs of the sugar mill in Queseria.

The national airport in the city of Colima $(5,207$ flights/year) would cancel services due to the ash in the air routes and airways. The Federal highway and roads that link Colima, Ciudad Guzman, Tamazula and the surrounding towns would be blocked for hours or days. The ash on the power stations in Ciudad Guzman and in Tamazula would cause short circuiting and blackouts.

\section{$0.5 \mathrm{~cm}$}

From $0.5 \mathrm{~cm}$ to $1 \mathrm{~cm}$ of ash fall would affect areas east of CV, between $64 \mathrm{~km}$ and $160 \mathrm{~km}$ from the crater. There are more than 700,000 people living in this area, who would be subject to similar effects as in scenario 1 with a $0.5 \mathrm{~cm}$ of ash. The tomato, bean and oat crops would be damaged, and the livestock would get sick because of the ash.

The area has national airports in Zamora (1,061 flights/year) and Uruapan (6,010 flights/year), so the ash would force these airports to close and the airways would need to be cleaned. The two main highways between Guadalajara and Colima and Morelia and Lazaro Cardenas link the Pacific with central Mexico. These roads would be closed because of low visibility and ash accumulation. The power stations in Colima, Sahuayo, Sayula, Uruapan and Zamora supply electricity to the region, and the ash would damage the transformers and cause blackouts.

\section{$0.1 \mathrm{~cm}$}

From $0.1 \mathrm{~cm}$ to $0.5 \mathrm{~cm}$ of ash would be expected between $160 \mathrm{~km}$ and $390 \mathrm{~km}$ from $\mathrm{CV}$, where more than 900,000 people are living in the city of Morelia and in small towns. The impact on the people and the economic activities would be similar to scenario 1 with $0.1 \mathrm{~cm}$ of ash. The ash would have positive effects on some agricultural areas, but the cattle would get sick, with reductions in meat and milk production.

Fine ash in the atmosphere would force the international airport in Morelia (18,144 flights/year) to shut down for days. The Lázaro Cárdenas-Morelia-México highways connect western Mexico and central Mexico, and the lack of visibility caused by the ash would create traffic problems.

The Cuitzeo and Patzcuaro lakes are habitats with endangered species, such as the white fish and Canadian duck. The ash would have adverse effects on the lake-water quality and ecology. During the 1980 Saint Helens eruption, the volcanic ash-leachates that fell in Richland Lake were toxic for the algal populations [McKnight et al. 1982].

\section{$0.01 \mathrm{~cm}$}

From $0.01 \mathrm{~cm}$ to $0.1 \mathrm{~cm}$ of ash-fall would be expected up to $725 \mathrm{~km}$ from CV. In this area, more the $25,000,000$ people live in Querétaro, Mexico City, Toluca, Puebla, Cuernavaca, Pachuca, Tula, Poza Rica and many small towns. The small amounts of ash would have minimal effects on crops, because it would be incorporated into the soil in days or weeks, and even be carried away by the wind.

In Salamanca, the petrochemical industry and refinery are important sources of income, as well as the thermoelectric power stations (including the one north of Mexico City). The ash in the atmosphere would increase the pollution in the environment and would cause respiratory problems for the people.

Fine ash would affect the international airports of Mexico City (355,593 flights/year) and Puebla (17,277 flights/year), Querétaro (12,733 flights/year), Toluca (unspecified flights) and Cuernavaca (unspecified flights), as well as the national airports in Celaya (2,400 flights/year) and Pachuca (3,707 flights/year), and cause deviation of air routes and interrupt operations for hours. The effects on the main highways and secondary roads would be small.

\section{Scenario 3}

In May the dominant wind blows to the north-northeast and north-northwest, which results in two possible scenarios.

Scenario 3 towards the north-northeast (Figure 6) would be similar to the 1913 eruption, when tephra fell on San Marcos, Tonila, Queseria, Ciudad Guzman, Zapotiltic, Tuxpan, Sayula, Guadalajara, Aguascalientes, Fresnillo, Zacatecas and Saltillo, and on small towns and farms [Waitz 1932].

\section{$100 \mathrm{~cm}$}

More than $100 \mathrm{~cm}$ of ash would be expected in the first $3 \mathrm{~km}$ on the north-north-eastern flank of CV. This area is covered by coniferous forest and alpine vegetation that would be buried, and the fauna would die. Ballistics would cause fires and burn the vegetation. The effects would be the same as in scenario 1 with $100 \mathrm{~cm}$ of ash.

\section{$50 \mathrm{~cm}$}

From $50 \mathrm{~cm}$ to $100 \mathrm{~cm}$ of ash would affect the southsouth-eastern portion of Nevado de Colima, between $3 \mathrm{~km}$ and $11 \mathrm{~km}$ from the CV crater. The coniferous forests and grasslands would be buried in ash. Small mammals, birds, insects and reptiles would die. The seismic and visual monitoring equipment and the radio and television microwave station on the northern flank of Nevado de Colima would be destroyed. 

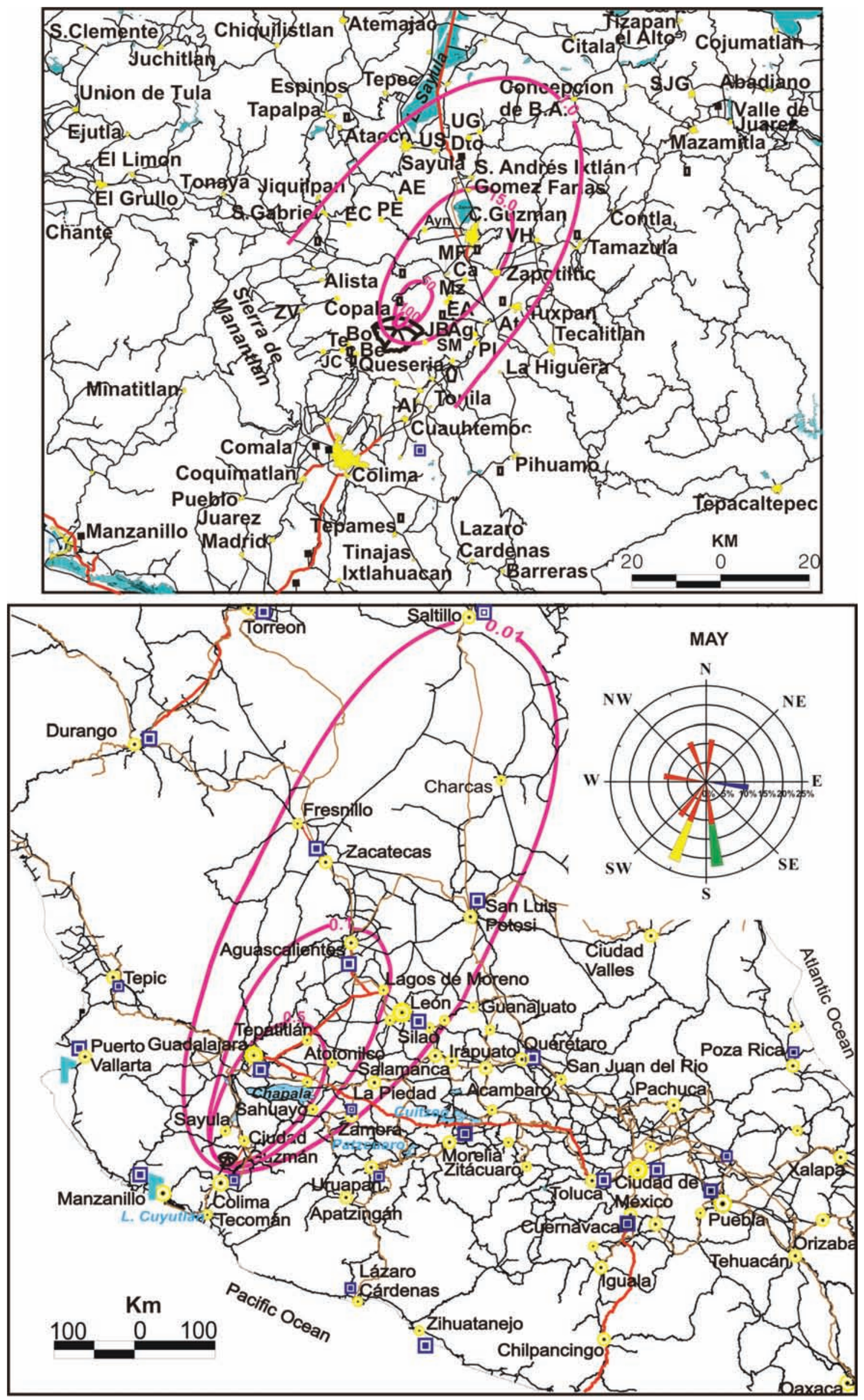

Figure 6. Scenario 3. For an eruption in May, showing the first potential, north-northeast, area that would be affected by a future Plinian eruption. For details, see legend to Figure 4. 


\begin{tabular}{|c|c|c|c|}
\hline Localities & $\begin{array}{l}\text { Population } \\
(2005)\end{array}$ & Main Economic Activities & Main Roads \\
\hline $\begin{array}{l}\text { Las Canoas } \\
\text { Ciudad Guzman } \\
\text { Ejido Atenquique } \\
\text { Gomez Farias } \\
\text { Juan Barragan } \\
\text { La Mesa y El Fresnito } \\
\text { Los Mazos } \\
\text { Zapotiltic }\end{array}$ & $\begin{array}{l}140 \\
93,609 \\
100 \\
6,535 \\
60 \\
900 \\
90 \\
21,440\end{array}$ & $\begin{array}{l}\text { Farming: sugar cane, corn } \\
\text { agave, sorghum, vegetables } \\
\text { pasture, pigs and pooultry } \\
\text { Ranching: cattle and goat } \\
\text { Industry: lumber and cement } \\
\text { Trade } \\
\text { Tourism }\end{array}$ & $\begin{array}{l}\text { Ciudad Guzmán-Guadalajara } \\
\text { Ciudad Guzmán-Colima }\end{array}$ \\
\hline $\begin{array}{l}\text { Alcaraces } \\
\text { Sayula } \\
\text { Atenquique } \\
\text { El Agosto } \\
\text { El Destacamento } \\
\text { El Platanar } \\
\text { Queseria } \\
\text { San Andres Ixtlan } \\
\text { San Gabriel } \\
\text { San Marcos } \\
\text { Tamazula } \\
\text { Tonila } \\
\text { Tuxpan } \\
\text { Unión de Guadalupe } \\
\text { Vista Hermosa }\end{array}$ & $\begin{array}{l}1,775 \\
27,311 \\
849 \\
301 \\
163 \\
452 \\
8,079 \\
4,665 \\
4,190 \\
3,179 \\
17,441 \\
3,099 \\
26,134 \\
873 \\
413\end{array}$ & $\begin{array}{l}\text { Farming: corn, sorghum } \\
\text { vegetables, legumes, lemon } \\
\text { sugar cane, coffee, grass } \\
\text { poultry and pigs, } \\
\text { Ranching: cattle }\end{array}$ & Guadalajara-Tuxpan \\
\hline $\begin{array}{l}\text { Guadalajara } \\
\text { Atotonilco el Alto } \\
\text { Poncitlan } \\
\text { Tepatitlàn } \\
\text { Ocotlàn } \\
\text { Concepcion BA } \\
\text { Tamazula } \\
\text { Sahuayo }\end{array}$ & $\begin{array}{l}4,295,853 \\
26,044 \\
13,105 \\
126,625 \\
81,165 \\
4,179 \\
17,441 \\
59,316\end{array}$ & $\begin{array}{l}\text { Industry: food, shoe, } \\
\text { pharmaceutical, textile } \\
\text { electronics and lumber } \\
\text { Tourism } \\
\text { Trade } \\
\text { Farming: corn, vegetable } \\
\text { sugar cane, pigs and poultry } \\
\text { Ranching: cattle, horse and } \\
\text { sheep }\end{array}$ & \\
\hline $\begin{array}{l}\text { Lagos de Moreno } \\
\text { Aguascalientes }\end{array}$ & $\begin{array}{l}92,712 \\
663,671\end{array}$ & $\begin{array}{l}\text { Farming: corn, alfalfa, onion } \\
\text { sorghum, beans, broccoli, } \\
\text { green beans, guava, grapes } \\
\text { pigs and poultry } \\
\text { Ranching: cattle and goat } \\
\text { Tourism } \\
\text { Trade } \\
\text { Industry: Chemical, textile, } \\
\text { automobile and construction }\end{array}$ & $\begin{array}{l}\text { Panamerican highway } \\
\text { Barra de Navidad-Tampico }\end{array}$ \\
\hline $\begin{array}{l}\text { Charcas } \\
\text { Fresnillo } \\
\text { Guanajuato } \\
\text { La Piedad } \\
\text { Leon and Silao } \\
\text { Saltillo } \\
\text { San Luis Potosí } \\
\text { Zacatecas } \\
\text { Zamora }\end{array}$ & $\begin{array}{l}20,173 \\
110,892 \\
70,798 \\
229,289 \\
1,278,087 \\
725,259 \\
685,934 \\
261,422 \\
127,606\end{array}$ & $\begin{array}{l}\text { Industry: shoe, leather, } \\
\text { textile and petrochemical } \\
\text { Trade } \\
\text { Tourism } \\
\text { Farming: corn, alfalfa, garlic } \\
\text { vegetables, grapes, grass, } \\
\text { poultry and pigs } \\
\text { Ranching: cattle, sheep and } \\
\text { goat }\end{array}$ & Panamerican highway \\
\hline
\end{tabular}

Table 7. Scenario 3. Localities, populations, main economic activities and roads which would be affected by different ash-fall levels during an eruption occurring in May (north-northeast level IV winds).

\section{$15 \mathrm{~cm}$}

From $15 \mathrm{~cm}$ to $50 \mathrm{~cm}$ of ash-fall would affect areas between $11 \mathrm{~km}$ and $38 \mathrm{~km}$ from $\mathrm{CV}$, where more than 120,000 people live (Table 7). These people would suffer from stress, skin and eye irritation, and respiratory problems. The effects on crops and livestock would be similar to scenario 1 with $15 \mathrm{~cm}$ of ash.

The Tolteca cement plant is a producer of lime, cement and marble, and it is located in Zapotiltic. The economic impact on this area would be significant, because of chimney obstruction and machinery damage in factories, which could paralyze production. Ash-fall and lightning would damage the alarm systems for lahars in Juan Barragan and Atenquique.

The main roads in this area are the Guadalajara-Ciudad Guzmán and Guadalajara-Colima highways, as well as the secondary roads that connect the towns near CV. The accumulation of ash would immediately paralyze transportation in the area.

\section{$>1.0 \mathrm{~cm}$}

From $1 \mathrm{~cm}$ to $15 \mathrm{~cm}$ of ash would be expected between $38 \mathrm{~km}$ and $64 \mathrm{~km}$ from CV. More than 70,000 people live in 
this area. The impact expected on people would be similar to previous scenarios with $>1.0 \mathrm{~cm}$ of ash. Orchards, sugar cane and corn, as well as forage grass in the early stages of growth, would be buried, and more mature plants would even suffer severely from the ash; the cattle would get sick. The sugar mill in Queseria, the cement factories in Zapotiltic, and the paper mill in Atenquique would be affected. Raw materials stored out in the open and the chimneys and roofs would be damaged.

The Colima-Guadalajara-Tuxpan highways have constant traffic and would be closed due to the lack of visibility and accumulation of ash. The power stations in Tuxpan and Sayula supply electricity to 43,936 users, and here the ash-fall would cause short circuits in transmission lines. Lightning would interrupt radio and television transmission at the microwave station in Tuxpan, and damage the alarms for lahars in San Marcos.

\section{$0.5 \mathrm{~cm}$}

From $0.5 \mathrm{~cm}$ to $1 \mathrm{~cm}$ of ash-fall would be expected between $64 \mathrm{~km}$ and $160 \mathrm{~km}$ from the CV crater, where there are more than 4,580,000 people. The ash would cause similar effects as in previous scenarios with $0.5 \mathrm{~cm}$ of ash. The economic activities would be affected temporarily by the lack of services and road access.

The highways that connect important cities, such as Colima, Guadalajara, Manzanillo, Ciudad Guzman, León, Morelia and Mexico City, would be affected by a lack of visibility, and ash accumulation would cause traffic problems. With the power stations in Guadalajara, Sahuayo, Ocotlan, Tamazula and Poncitlan, which supply electricity to more 600,000 users, the ash would cause power shortages and blackouts. The international airport in Guadalajara would be forced to close operations for hours or days.

Lake Chapala would also be affected by ash deposition, and the effects would be similar to scenario 1 with $0.5 \mathrm{~cm}$ of ash.

\section{$0.1 \mathrm{~cm}$}

From $0.1 \mathrm{~cm}$ to $0.5 \mathrm{~cm}$ of ash would be expected between $160 \mathrm{~km}$ and $390 \mathrm{~km}$ north-northeast from the CV crater. There are more than 900,000 inhabitants in this area, and the ash would cause skin, eye and respiratory problems. This is one of the main milk-producing areas in the country, which supplies the markets of Guadalajara, Aguascalientes and Mexico City. The impact on economic activities would be similar to those in scenario 1 with $0.1 \mathrm{~cm}$ of ash.

The Panamerican, Barra de Navidad-Tampico and Guadalajara highways connect with Morelia, Querétaro, México City and Aguascalientes. The lack of visibility due to the ash would cause traffic jams. The power stations in Aguascalientes and Lagos de Moreno supply electricity to more than 300,000 users, and there would be blackouts.
Furthermore, the international airport in Aguascalientes would interrupt operations for hours due to the ash in the atmosphere.

\section{$0.01 \mathrm{~cm}$}

From $0.01 \mathrm{~cm}$ to $0.1 \mathrm{~cm}$ of ash would be expected up to $725 \mathrm{~km}$ from CV. There are more than 3 million inhabitants in this area, in Leon, San Luis Potosí, Zacatecas, Guanajuato and Saltillo, and in small towns. The effects would be similar to scenario 1 with $0.01 \mathrm{~cm}$ of ash.

The power stations in San Luis Potosi and Saltillo, and the main roads like the Panamerican highway, would suffer minimal effects. This scenario includes the international airports of Leon (27,206 flights/year), San Luis Potosi (24,430 flights/year), Zacatecas (8,257 flights/year) and Saltillo (13,165 flights/year), and the national airport in Zamora (1,061 flights/year). Fine ash would lead to flight cancellations, due to the fine ash in the air.

\section{Scenario 4}

In May, the winds also blow north-north-westerly, resulting in this second May scenario (Figure 7).

\section{$100 \mathrm{~cm}$}

More than $100 \mathrm{~cm}$ of tephra would be expected $3 \mathrm{~km}$ from the $\mathrm{CV}$ crater, on the north-north-western flank of CV. The coniferous forest would be covered by ash and pumice, and wild animals would be buried, as in previous scenarios with $100 \mathrm{~cm}$ of ash.

\section{$50 \mathrm{~cm}$}

From $50 \mathrm{~cm}$ to $100 \mathrm{~cm}$ of ash would be expected between $3 \mathrm{~km}$ and $11 \mathrm{~km}$ from the CV crater on the southsouth-western sector of the Nevado de Colima (Table 8). This zone is covered by coniferous forests and grasslands, where wild animals live, such as small mammals, and many types of birds, insects and reptiles. The impact expected on the vegetation and fauna would be similar to that in previous scenarios with $50 \mathrm{~cm}$ of ash. The ash, pumice and lapilli would also damage the microwave station on the northern flank of Nevado Volcano and the seismic and visual monitoring equipment at Nevado, $5.3 \mathrm{~km}$ from the CV crater.

\section{$15 \mathrm{~cm}$}

From $15 \mathrm{~cm}$ to $50 \mathrm{~cm}$ of ash would fall between $11 \mathrm{~km}$ and $38 \mathrm{~km}$ to the north-northwest of CV. More than 4,210 people live in this area, who would be subject to stress, and eye, skin and respiratory problems. Ash-fall would bury crops (tomatoes and potatoes) and cause roofs of greenhouses to collapse. Livestock would get sick or die after consuming contaminated pasture and water. San Gabriel has a power station and a radio and television microwave station, 

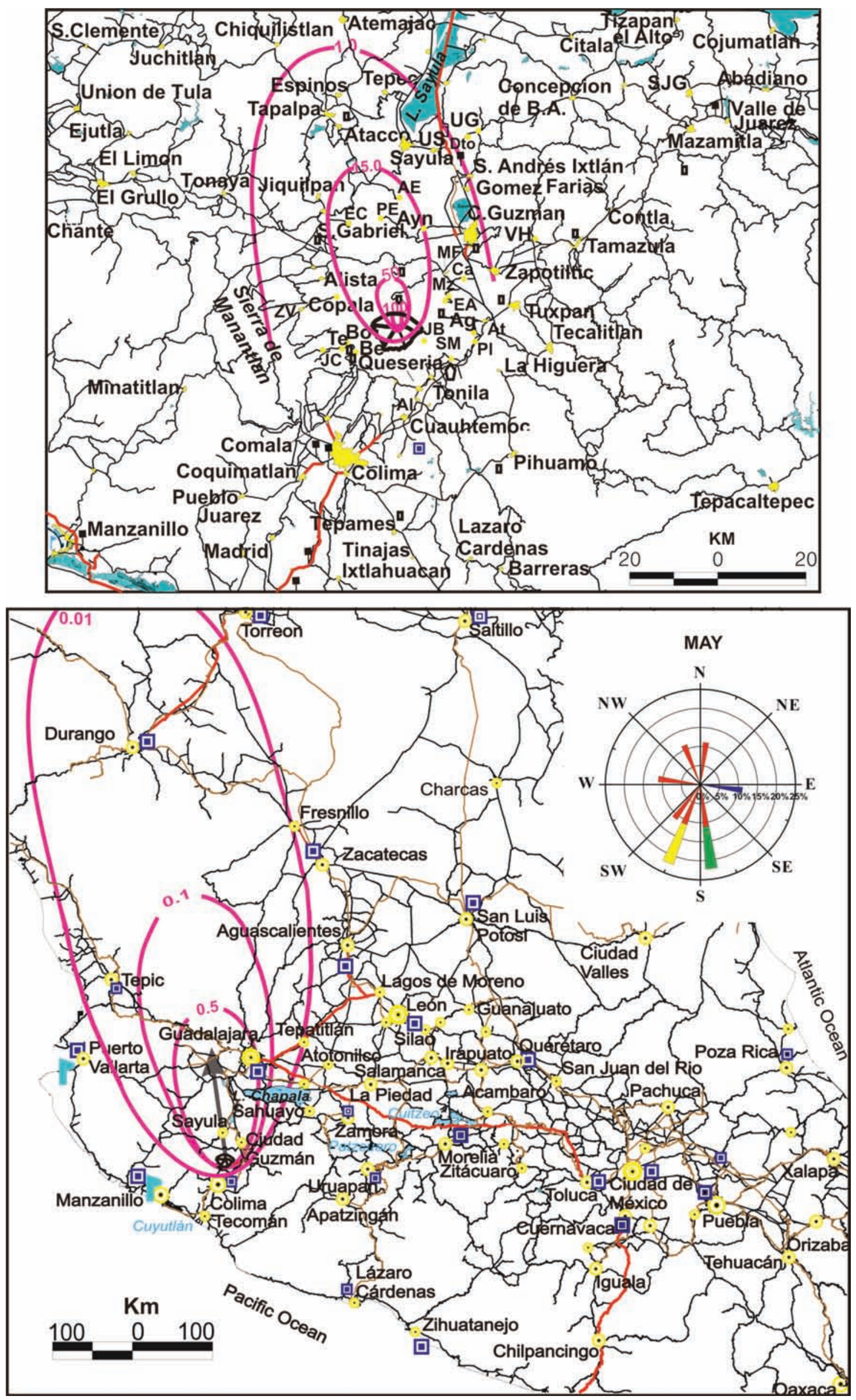

Figure 7. Scenario 4. For an eruption in May, showing the second potential, north-northwest, area that would be affected by a future Plinian eruption. For details, see legend to Figure 4. 


\begin{tabular}{|c|c|c|c|}
\hline Localities & $\begin{array}{l}\text { Population } \\
(2005)\end{array}$ & Economic Activities & Main Roads \\
\hline $\begin{array}{l}\text { San Gabriel } \\
\text { Agua Escondida } \\
\text { Los Pozos y El Ocote } \\
\text { El Carpintero }\end{array}$ & $\begin{array}{l}4,190 \\
16 \\
4 \\
15\end{array}$ & $\begin{array}{l}\text { Trade } \\
\text { Farming: corn, potatoes, tomatoes } \\
\text { pigs and poultry } \\
\text { Ranching: cattle and sheep }\end{array}$ & Guadalajara-San Gabriel \\
\hline $\begin{array}{l}\text { Alista } \\
\text { Atacco } \\
\text { Atenquique } \\
\text { Ciudad Guzman } \\
\text { Copala } \\
\text { Ejido Atenquique } \\
\text { El Agosto } \\
\text { El Platanar } \\
\text { Gomez Farias } \\
\text { Jiquilpan } \\
\text { Juan Barragan } \\
\text { La Mesa y el Fresnito } \\
\text { Las Canoas } \\
\text { Los Espinos } \\
\text { Los Mazos } \\
\text { Queseria } \\
\text { San Andres Ixtlán } \\
\text { San Marcos } \\
\text { Sayula } \\
\text { Tapalpa } \\
\text { Tepec } \\
\text { Tonila } \\
\text { Tuxpan } \\
\text { Usmajac } \\
\text { Zapotiltic }\end{array}$ & $\begin{array}{l}971 \\
1,021 \\
849 \\
93,609 \\
455 \\
110 \\
301 \\
452 \\
6,535 \\
1,656 \\
60 \\
800 \\
131 \\
625 \\
190 \\
8,079 \\
4,665 \\
3,179 \\
27,311 \\
5,301 \\
1,743 \\
3,099 \\
26,134 \\
6,811 \\
21,440\end{array}$ & $\begin{array}{l}\text { Farming: sugar cane, agave, peach, } \\
\text { vegetables, pomegranate, guava, } \\
\text { corn, sorghum, poultry and pigs } \\
\text { Ranching: cattle and sheep } \\
\text { Industry: cement and paper }\end{array}$ & $\begin{array}{l}\text { Guadalajara-Colima-Manzanillo } \\
\text { Ciudad Guzman-Colima } \\
\text { Guadalajara-Sayula-San Gabriel } \\
\text { El Grullo-Tonaya-San Gabriel } \\
\text { Guadalajara-Jiquilpan-Mexico }\end{array}$ \\
\hline $\begin{array}{l}\text { Atemajac } \\
\text { Chiquilistlan } \\
\text { Concepción de Buenos Aires } \\
\text { Contla } \\
\text { Ejutla } \\
\text { El Destacamento } \\
\text { El Grullo } \\
\text { Guadalajara } \\
\text { Juchitlán } \\
\text { Lázaro Cárdenas } \\
\text { El Limón } \\
\text { Mazamitla } \\
\text { Quitupan } \\
\text { San Clemente } \\
\text { San Juan de Amula } \\
\text { Tecaltitlán } \\
\text { Tizapan el Alto } \\
\text { Tonaya } \\
\text { Union de Guadalupe } \\
\text { Unión de tula } \\
\text { Valle de Juárez } \\
\text { Vista Hermosa }\end{array}$ & $\begin{array}{l}28 \\
3,416 \\
4,179 \\
34 \\
1,229 \\
163 \\
19,364 \\
4,295,853 \\
3,403 \\
1,014 \\
2,965 \\
7,096 \\
152 \\
1,078 \\
488 \\
3,066 \\
13,755 \\
3,238 \\
873 \\
8,589 \\
3,575 \\
8\end{array}$ & $\begin{array}{l}\text { Industry: auto, food, pharmaceutical, } \\
\text { electronics, textile and lumber } \\
\text { Tourism } \\
\text { Trade } \\
\text { Farming: corn, sugar cane, } \\
\text { Ranching: cattle, sheep and goat }\end{array}$ & $\begin{array}{l}\text { Guadalajara-Manzanillo } \\
\text { Guadalajara-Morelia } \\
\text { Guadalajara-Saltillo } \\
\text { Guadalajara-Barra de Navidad } \\
\text { El Grullo-Ciudad Guzmán } \\
\text { Guadalajara-Tuxcueca-Mazamitla } \\
\text { Ixtlahuacán Del Río-Cuquío }\end{array}$ \\
\hline \multicolumn{4}{|l|}{ Sierra Huichol } \\
\hline $\begin{array}{l}\text { Tepic } \\
\text { Fresnillo } \\
\text { Durango } \\
\text { Zacatecas } \\
\text { Tepatitlán } \\
\text { Ocotlán }\end{array}$ & $\begin{array}{l}379,296 \\
110,892 \\
526,659 \\
122,889 \\
82,975 \\
81,165\end{array}$ & $\begin{array}{l}\text { Trade } \\
\text { Tourism } \\
\text { Farming: corn, avocado, sugar cane, } \\
\text { coffee, chile, mango, banana, } \\
\text { tobacco, pigs and poultry } \\
\text { Ranching: cattle, horse, sheep and } \\
\text { goat }\end{array}$ & $\begin{array}{l}\text { Panamerican highway } \\
\text { Matamoros-Mazatlán }\end{array}$ \\
\hline
\end{tabular}

Table 8. Scenario 4. Localities, populations, main economic activities and roads which would be affected by different ash-fall levels during an eruption occurring in May (north-northwest level IV winds).

where the transformers and towers would be damaged by lightning during the eruption, which would cause shortages and lack of electricity. The Guadalajara-San Gabriel highway would be closed.

$$
>1 \mathrm{~cm}
$$

From $1 \mathrm{~cm}$ to $15 \mathrm{~cm}$ would be expected between $38 \mathrm{~km}$ and $64 \mathrm{~km}$ north-northwest of the CV crater, where 150,000 people live in many towns. The effects on the people and economic activities would be similar to scenario 1 with more than $1 \mathrm{~cm}$ of ash. The cement factories in Zapotiltic would be affected.

Power stations in San Gabriel, Sayula, Ciudad Guzman, Gomez Farias, Tuxpan and Zapotiltic supply electricity to more 70,000 users. The ash and lightning would cause short circuits in transmission lines. The radio and television microwave stations in Sayula, Tuxpan and Ciudad Guzman would suffer transmission problems due to ash interference. 
Main highways, such as the Guadalajara-Manzanillo and Guadalajara-Sayula highways (and the Guadalajara-Nogales railroad) that link the Pacific Coast to north-central Mexico would have traffic jams towards Guadalajara or the Pacific due to ash on the roads.

The $\mathrm{pH}$ and nutrient conditions in the Zapotlan and Sayula Lagoons would be modified by ash silting, and the native plants and animals would die.

\section{$0.5 \mathrm{~cm}$}

From $0.5 \mathrm{~cm}$ to $1 \mathrm{~cm}$ could be expected between $64 \mathrm{~km}$ and $160 \mathrm{~km}$ from CV, where around 4,332,049 people live; the impact of the ash would be the same as scenario 1 with a $0.5 \mathrm{~cm}$ thickness. The economy would be affected temporarily by the lack of services and road access.

The Guadalajara international airport would have to close operations for hours or days due to ash clouds and ash over the airstrips. The power stations in Guadalajara, Cuquio, El Grullo, Mazamitla, Unión de Tula and Valle de Juarez supply electricity to over one million users, and the ash would cause power shortages and blackouts. The microwave stations in Guadalajara, El Grullo and Mazamitla would have interference problems. Main roads, such as the Guadalajara-Manzanillo and Guadalajara-Saltillo ones, would have traffic problems due to lack of visibility.

Lake Chapala would also have serious pollution due to the ash, as in scenario 1 with 0.5 thickness.

$0.1 \mathrm{~cm}$

From $0.1 \mathrm{~cm}$ to $0.5 \mathrm{~cm}$ of ash would be expected between $160 \mathrm{~km}$ and $390 \mathrm{~km}$ north-northwest from CV. The socioeconomic effects over the Sierra Huicholes area would be minimal due to the lower population density.

$0.01 \mathrm{~cm}$

From $0.01 \mathrm{~cm}$ to $0.1 \mathrm{~cm}$ of ash would be expected up to $725 \mathrm{~km}$ to the north-northwest of CV. More than 1,303,876 people live in this area, in Tepic, Fresnillo, Durango and Zacatecas. The fine ash would cause effects similar to those in scenario 1 with $0.01 \mathrm{~cm}$ of ash.

Tepic has two refineries that represent major sources of employment for local households throughout the state. The hydroelectric plants in Tepic and Durango, with capacity from 320 megawatts to 960 megawatts, are the most important power production facilities in the area. The ash in the atmosphere would increase the pollution in this area.

The Mazatlán highway that connects México City with north-western Mexico would see small effects. The power and microwave stations in Tepic, Fresnillo, Durango and Zacatecas would have interference due to the ash. There are international airports in Zacatecas (8,257 flights/year) and Durango (15,676 flights/year), as well as a national airport in Tepic (10,837 flights/year), which would be forced to interrupt operations for hours or cause deviations to their air routes.

\section{Scenario 5}

From June to August, there is a high probability that the winds would blow towards the northwest (Figure 8).

\section{$100 \mathrm{~cm}$}

More than $100 \mathrm{~cm}$ of tephra would be expected $3 \mathrm{~km}$ from the CV crater on the north-western flank of CV. This area is also covered by coniferous forests and grassland that would be buried by ash, pumice and lapilli. Birds, insects and reptiles would die, as in previous scenarios with $100 \mathrm{~cm}$ of ash.

\section{$50 \mathrm{~cm}$}

From $50 \mathrm{~cm}$ to $100 \mathrm{~cm}$ of ash would be expected between $3 \mathrm{~km}$ and $11 \mathrm{~km}$ from CV, on the north-western side of CV. The coniferous forest and grass would be buried by ash, pumice and lapilli, and fires would burn the vegetation. The local fauna of this zone would die.

\section{$15 \mathrm{~cm}$}

From $15 \mathrm{~cm}$ to $50 \mathrm{~cm}$ of ash could affect areas between $11 \mathrm{~km}$ and $38 \mathrm{~km}$ from the CV crater, where more than 9,150 inhabitants live (Table 9). The immediate effects on the population would be stress, and skin, eye and respiratory problems, with an impact on trade, farming, ranching and industry, similar to scenario 4 with $15 \mathrm{~cm}$ of ash.

The Guadalajara-Ciudad Guzmán and Guadalajara-San Gabriel roads would be forced to close temporarily to remove the ash. Furthermore, the microwave stations in San Gabriel and on the northern flank of CV would have interference problems during ash-fall. San Gabriel has a power station and the transformers would be damaged by lightning, which would cause a lack of electric power for several days. Zapotitlan de Vadillo has a runway for aeroplanes, which would be obstructed by ash accumulation.

\section{$>1 \mathrm{~cm}$}

From $1 \mathrm{~cm}$ to $15 \mathrm{~cm}$ of ash would be expected between $38 \mathrm{~km}$ and $64 \mathrm{~km}$ northwest of CV. Around 30,123 people live in this area, who would have problems as in previous scenarios with $>1 \mathrm{~cm}$ of ash. The Borbollon, Schulte and El Jabali ranches are private environmental protection areas that have sustainable management of natural resources. Likewise, the Hacienda San Antonio, a luxury hotel, and the La Maria Lake cabins employ local people. Furthermore, mountain biking and picnicking are important week-end activities around the CV and the Nevado de Colima, which would be closed for several months.

Zapotiltic and Atenquique would experience increased aerosol contents in the atmosphere, and the machinery and 


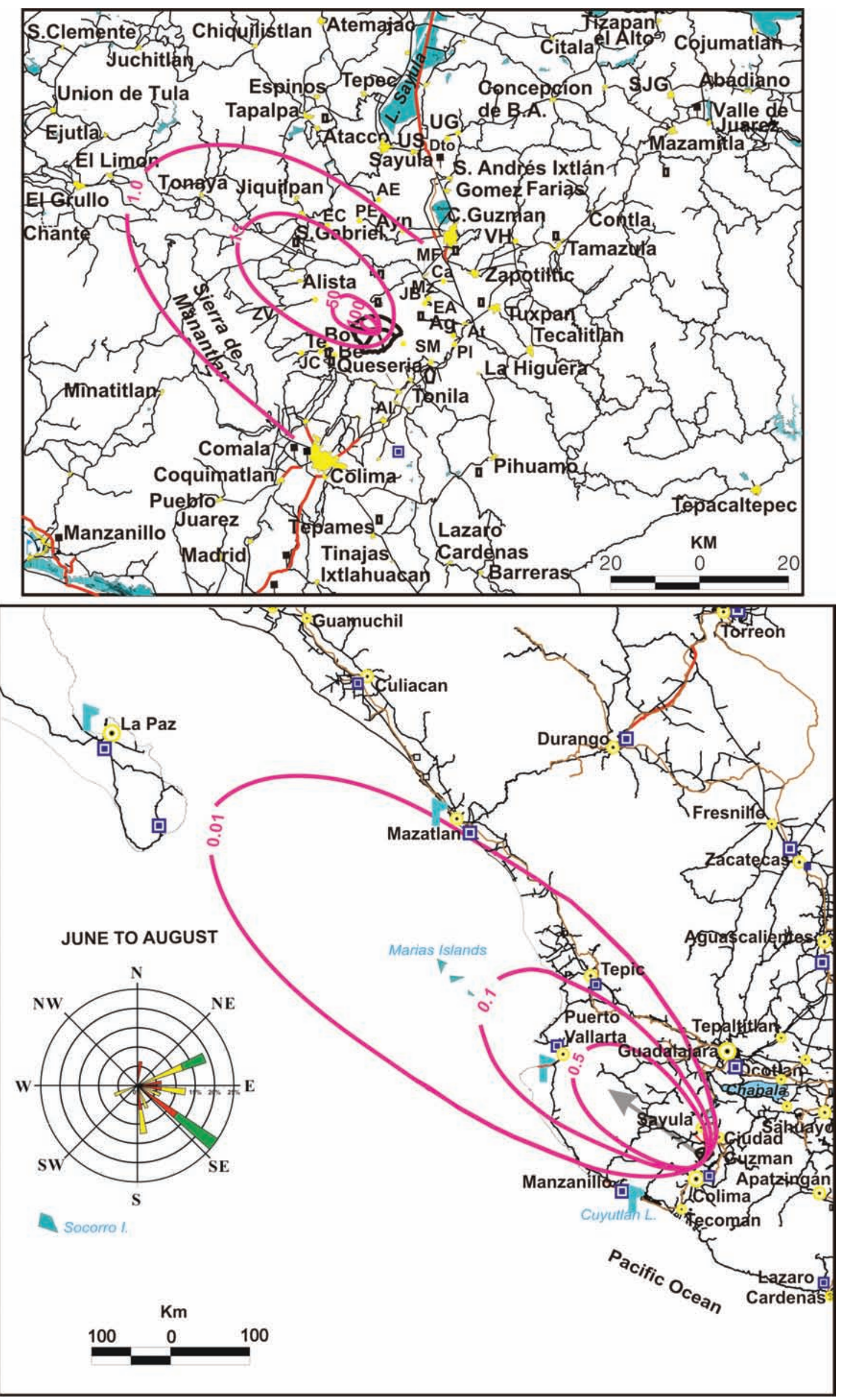

Figure 8. Scenario 5. For an eruption from June to August, showing the northwest area that would be affected by a future Plinian eruption. For details, see legend to Figure 4. 


\begin{tabular}{|c|c|c|c|c|}
\hline $\begin{array}{l}\begin{array}{l}\text { Ash Thickness } \\
\text { (cm) }\end{array} \\
\end{array}$ & Localities & $\begin{array}{l}\begin{array}{l}\text { Population } \\
(2005)\end{array} \\
\end{array}$ & Economic Activities & Main Roads \\
\hline 15 & $\begin{array}{l}\text { San Gabriel } \\
\text { Zapotitlán de Vadillo } \\
\text { Copala } \\
\text { Alista }\end{array}$ & $\begin{array}{l}4,190 \\
3,115 \\
455 \\
971\end{array}$ & $\begin{array}{l}\text { Trade } \\
\text { Farming: corn, tomatoes, sugar cane, } \\
\text { agave, vegetables, potatoes, lemon, } \\
\text { guava, mango and red plum orchards, } \\
\text { pigs and poultry } \\
\text { Ranching: cattle and sheep }\end{array}$ & $\begin{array}{l}\text { Guadalajara-Ciudad Guzmán } \\
\text { Guadalajara-Sayula-San Gabriel } \\
\text { Zapotitlán de Vadillo-San J. Del Cármen } \\
\text { San Gabriel-Zapotitlán de Vadillo }\end{array}$ \\
\hline$>1.0$ & $\begin{array}{l}\text { El Tecuan } \\
\text { Cofradía de Suchitlán } \\
\text { Comala } \\
\text { Ejido Atenquique } \\
\text { El Borbollón } \\
\text { El Jabalì } \\
\text { Hacienda San Antonio } \\
\text { Jiquilpan } \\
\text { Juan Barragan } \\
\text { Juan Barragan } \\
\text { La Becerrera } \\
\text { La Mesa y el Fresnito } \\
\text { La Yerbabuena } \\
\text { Las Canoas } \\
\text { Los Mazos } \\
\text { San José del Carmen } \\
\text { Suchitlán } \\
\text { Tonaya } \\
\text { Zapotiltic }\end{array}$ & $\begin{array}{l}101 \\
1,601 \\
8,927 \\
110 \\
12 \\
4 \\
\\
1,656 \\
60 \\
60 \\
274 \\
800 \\
31 \\
131 \\
190 \\
775 \\
4,083 \\
3,228 \\
21,44 \\
\end{array}$ & $\begin{array}{l}\text { Trade } \\
\text { Tourism } \\
\text { Industry: cement } \\
\text { Farming: legumes, cereals, agave } \\
\text { sugar cane, coffee, vegetables, } \\
\text { lemon, cucumber, rice, sorghum, } \\
\text { corn and nuts, papaya, tamarind, } \\
\text { oranges, watermelon, cantaloupe } \\
\text { tamarind, poultry and goat } \\
\text { Ranching: cattle }\end{array}$ & $\begin{array}{l}\text { Comala-Zapotitlán de Vadillo } \\
\text { Carrizalillos-Quesería } \\
\text { Manzanillo-Colima }\end{array}$ \\
\hline 0.5 & $\begin{array}{l}\text { Atemajac } \\
\text { Chiquilistlan } \\
\text { Concepción BA } \\
\text { Cuquio } \\
\text { Ejutla } \\
\text { El Destacamento } \\
\text { El Grullo } \\
\text { Juchitlán } \\
\text { Chiquilistlán } \\
\text { El Limón } \\
\text { Mazamitla } \\
\text { Minatitlán } \\
\text { San Clemente } \\
\text { Sayula } \\
\text { Union de Guadalupe } \\
\text { Unión de tula }\end{array}$ & $\begin{array}{l}28 \\
3,416 \\
4,179 \\
4,122 \\
1,229 \\
163 \\
19,364 \\
3,403 \\
3,416 \\
2,965 \\
7,096 \\
3,961 \\
1,078 \\
27,311 \\
873 \\
8,589 \\
\end{array}$ & $\begin{array}{l}\text { Trade } \\
\text { Farming: corn, sugar cane, } \\
\text { vegetables, grassland, pigs } \\
\text { Ranching: cattle, sheep and goat }\end{array}$ & $\begin{array}{l}\text { Guadalajara-Manzanillo } \\
\text { Guadalajara-Barra de Navidad } \\
\text { El Grullo-Ciudad Guzmán } \\
\text { Ixtlahuacán-Cuquío }\end{array}$ \\
\hline 0.1 & $\begin{array}{l}\text { Tepic } \\
\text { Puerto Vallarta } \\
\text { Ahuacatlán }\end{array}$ & $\begin{array}{l}379,296 \\
304,107 \\
6,430\end{array}$ & $\begin{array}{l}\text { Tourism } \\
\text { Industry: manufacturing, refineries } \\
\text { Trade } \\
\text { Farming: sugar cane, coffee, chile, } \\
\text { sweet corn, watermelon, mango, } \\
\text { banana, avocado, peas, pigs, poultry } \\
\text { Ranching; cattle and goat }\end{array}$ & $\begin{array}{l}\text { Pacific highway } \\
\text { Guadalajara-Puerto Vallarta } \\
\text { Guadalajara-Tepic-Mazatlán } \\
\text { Tepic-Puerto Vallarta }\end{array}$ \\
\hline 0.01 & $\begin{array}{l}\text { Colima } \\
\text { Mazatlán } \\
\text { Islas Marias } \\
\text { Santa Maria del Oro } \\
\text { Escuinapa } \\
\text { Acaponeta } \\
\text { Puerto Balleto }\end{array}$ & $\begin{array}{l}294,828 \\
352,471 \\
1,116 \\
4,208 \\
28,789 \\
18,066 \\
602\end{array}$ & $\begin{array}{l}\text { Tourism } \\
\text { Fishing: shrimp, tuna and mullet } \\
\text { Trade } \\
\text { Industry: food, coffee and beer } \\
\text { Farrming: corn, tobacco, sugar cane, } \\
\text { mango, lemon, plum, avocado, dates, } \\
\text { and coconut, pigs and poultry } \\
\text { Ranching: cattle, goats, ducks and } \\
\text { geese }\end{array}$ & $\begin{array}{l}\text { Colima-Manzanillo } \\
\text { Manzanillo-Puerto Vallarta } \\
\text { Manzanillo-Tepic-Guadalajara } \\
\text { México-Nogales }\end{array}$ \\
\hline
\end{tabular}

Table 9. Scenario 5. Localities, populations, main economic activities and roads which would be affected by different ash-fall levels during an eruption occurring from June to August.

chimneys of the paper and cement industries would be damaged by ash abrasion. Silting of the Zarco and La Lumbre rivers due to accumulation of pyroclastic material would trigger the formation of lahars during the summer. The Lumbre and Zarco bridges would be damaged, thus blocking the San José del Cármen-Suchitlán road.

The sector to the west of CV has a network of roads, such as the Manzanillo-Colima, the Comala-San José del CármenZapotitlán de Vadillo, and the Carrizalillos-Quesería highways, which would be blocked by ash accumulation. Power stations in Zapotiltic supply electricity to more 10,247 users. The ash and lightning would cause short circuits in distribution lines. The microwave station in la Becerrera would also have transmission problems due to interference or ash abrasion.

\section{$0.5 \mathrm{~cm}$}

From $0.5 \mathrm{~cm}$ to $1 \mathrm{~cm}$ of ash would be expected between $64 \mathrm{~km}$ and $160 \mathrm{~km}$ to the northwest of the volcano, where there are more than 87,777 people. The expected impact on people, trade, farming and cattle ranching would be similar to scenario 1 with $0.5 \mathrm{~cm}$ of ash.

The Guadalajara-Manzanillo, Guadalajara-Barra de Navidad and El Grullo-Ciudad Guzmán highways would have poor visibility and would experience traffic problems. The radio and television stations in El Grullo and Mazamitla would have interference problems. In this area, the power stations in Cuquio, El Grullo, Unión de Tula and Valle de Juarez supply electricity to countless users. The ash would cause power shortages and blackouts. 
In the Zapotlán and Sayula Lagoons, the ash-fall would produce contamination by silting and modification of the conditions of $\mathrm{pH}$ and nutrients.

\section{$0.1 \mathrm{~cm}$}

From $0.1 \mathrm{~cm}$ to $0.5 \mathrm{~cm}$ of ash would be expected between $160 \mathrm{~km}$ and $390 \mathrm{~km}$ on the north-western side of CV. This area has 689,833 inhabitants, in Tepic, the Puerto Vallarta metropolitan area, and many towns. Puerto Vallarta the third largest port in Mexico, and it receives more than 5 million tourists each year. The economy of the area depends on tourism, which accounts for roughly $50 \%$ of all of the economic activity in the Puerto Vallarta metropolitan area. The manufacturing industry and refineries in Tepic, and the hydroelectric plants in Aguamilpa and Jumatan are the chief income sources for the local population. Other important sources are trade, farming and cattle ranching. Tourism during the summer would be paralyzed for hours or days due to ash-fall.

The Pacific highway and the Guadalajara-Vallarta, TepicMazatlan freeways would have traffic problems. Puerto Vallarta also has a maritime infrastructure that provides services to cruise ships and private boats, and provides local tourist transportation. The microwave stations in Tepic and Puerto Vallarta would have interference of the radio and television signals, and the ash would paralyze these activities for hours or days. The international airports in Puerto Vallarta (38,892 flights/year) and Tepic (10,837 flights/year) would be forced to interrupt flights for hours, and would require clean-up operations on the runways and aircraft.

\section{$0.01 \mathrm{~cm}$}

From $0.01 \mathrm{~cm}$ to $0.1 \mathrm{~cm}$ of ash would be expected between $390 \mathrm{~km}$ and $725 \mathrm{~km}$ from CV. In this area, there are more than 699,373 inhabitants, in the Colima metropolitan area, and in Mazatlán, Islas Marias and small towns. Mazatlan is one of the most important Mexican ports because of its international trade and cruise-related tourism from the United States, and it is the main link with the La Paz port in Baja, California. Furthermore, the Islas Marías are four islands where the Marias Prison is located. Nonetheless the impact would be minimal.

The power stations in Mazatlan and Colima, as well as the Colima-Manzanillo, Guadalajara-Tepic and MexicoNogales roads, would expect little damage. The airports in Manzanillo (8,004 flights / year), Mazatlan (no data), Colima (5,207 flights/year), and the private airport in Escuinapa, would be affected by the ash in the atmosphere.

\section{Scenario 6}

In September, the predominant wind direction is westerly, and ash would be expected to be scattered in the same direction (Figure 9).

\section{$100 \mathrm{~cm}$}

More than $100 \mathrm{~cm}$ would fall up to $3 \mathrm{~km}$ from the CV crater, on the western flank of CV. This area is also covered by coniferous forests that are associated with natural grasslands. The ash would bury the vegetation and the wild animals, and especially the birds, insects and reptiles would die.

\section{$50 \mathrm{~cm}$}

From $50 \mathrm{~cm}$ to $100 \mathrm{~cm}$ of ash would be expected between $3 \mathrm{~km}$ and $11 \mathrm{~km}$ on the western side of CV. The ashfall would bury the coniferous forests and natural grasslands. The wildlife would die, as in previous scenarios with $50 \mathrm{~cm}$ of ash. The impact would become significant for private areas, such as the El Jabali, Shulte and El Borbollon ranches in the southwest, because they would be destroyed. The coffee, corn and agave crops, and orchards and livestock would be covered by the ash.

\section{$15 \mathrm{~cm}$}

From $15 \mathrm{~cm}$ to $50 \mathrm{~cm}$ of ash-fall would affect areas west of CV. In this area, there are more than 5,738 inhabitants, who would suffer eye, skin and respiratory problems, as well as nervousness, as for the previously described scenarios with $15 \mathrm{~cm}$ thickness (Table 10). The ash would cover the crops and the cattle would die or have gastrointestinal diseases after eating contaminated grass.

The Zapotitlán de Vadillo-Guadalajara road would be closed, and it would be necessary to remove the ash. The radio and television microwave station in La Becerrera would be damaged during the ash-fall. The runways for aeroplanes in Zapotitlan Vadillo and at the Jabali ranch would be obstructed by ash accumulation.

\section{$>1 \mathrm{~cm}$}

From $1 \mathrm{~cm}$ to $15 \mathrm{~cm}$ of ash would be expected between $38 \mathrm{~km}$ and $64 \mathrm{~km}$ to the west side of $\mathrm{CV}$, an area that has more than 319,840 inhabitants. The population would experience the same impact as in scenario 1 with $>1 \mathrm{~cm}$ of ash. The cereal crops would be damaged during the pollination period, thus reducing grain quality; livestock would get sick or die by eating contaminated pasture.

The state roads connecting Zapotitlán de Vadillo-Colima and Colima-Puerto Vallarta would be closed due to lack of visibility and accumulation of ash. The power stations in Colima supply electricity to 54,939 users, and it would suffer blackouts due to short circuits. The microwave station in San Gabriel would have transmission problems, and the airport in Colima would be forced to close operations, to remove the ash from the aeroplanes, runways and taxiways.

\section{$0.5 \mathrm{~cm}$}

From $0.5 \mathrm{~cm}$ to $1 \mathrm{~cm}$ of ash would be expected between $64 \mathrm{~km}$ and $160 \mathrm{~km}$ to the western side of $\mathrm{CV}$, where there 


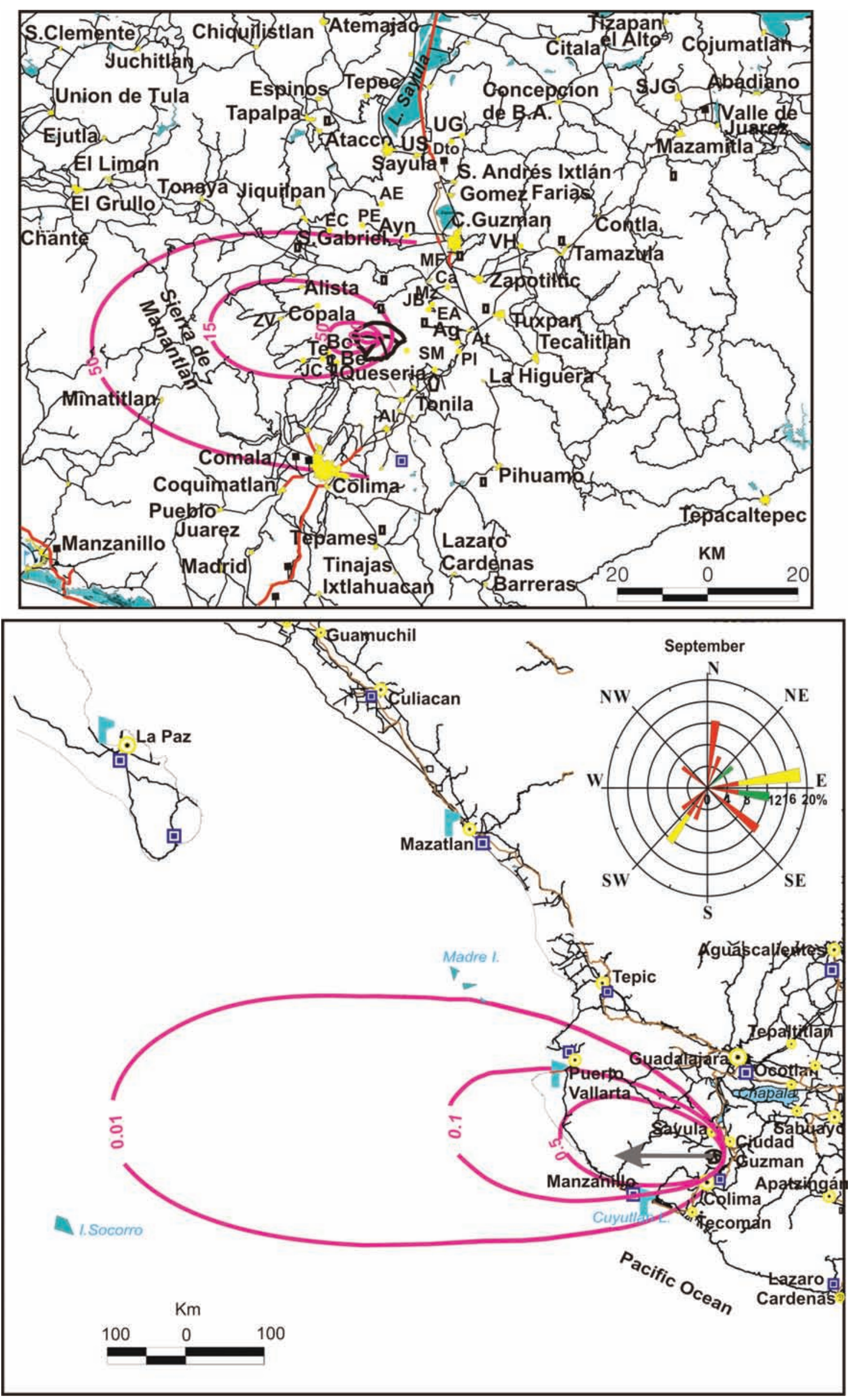

Figure 9. Scenario 6. For an eruption in September, showing the western area that would be affected by a future Plinian eruption. For details, see legend to Figure 4. 


\begin{tabular}{|c|c|c|c|c|}
\hline $\begin{array}{l}\text { Ash Thickness } \\
\text { (cm) }\end{array}$ & Localities & $\begin{array}{l}\text { Population } \\
(2005)\end{array}$ & Economic Activities & Main Roads \\
\hline 50 & $\begin{array}{l}\text { Shulte ranch } \\
\text { Borbollón ranch } \\
\text { El Jabalí ranch }\end{array}$ & $\begin{array}{l}0 \\
12 \\
4\end{array}$ & $\begin{array}{l}\text { Tourism } \\
\text { trade } \\
\text { Farming: agave, corn, sugar cane, agave } \\
\text { lemon, vegetables, pigs and poultry } \\
\text { Ranching: cattle }\end{array}$ & secondary roads \\
\hline 15 & $\begin{array}{l}\text { Hacienda San Antonio } \\
\text { La Yerbabuena } \\
\text { La Becerrera } \\
\text { El Tecuan } \\
\text { San José del Carmen } \\
\text { Zapotitlan de Vadillo } \\
\text { Alista } \\
\text { Copala }\end{array}$ & $\begin{array}{l}\text { no data } \\
31 \\
274 \\
101 \\
775 \\
3,115 \\
971 \\
455\end{array}$ & $\begin{array}{l}\text { Trade } \\
\text { Tourism } \\
\text { Farming: corn, agave, legume, cereals, } \\
\text { sugar cane, coffee, vegetables, sorghum, } \\
\text { lemon, peach, guava, oranges, poultry } \\
\text { and pigs } \\
\text { Ranching: Cattle and goat }\end{array}$ & $\begin{array}{l}\text { Zapotitlán de Vadillo-Colima } \\
\text { Zapotitlán de Vadillo-Guadalajara }\end{array}$ \\
\hline$>1.0$ & $\begin{array}{l}\text { Alcaraces } \\
\text { Cofradia de Suchitlan } \\
\text { Colima } \\
\text { Comala } \\
\text { Cuauhtemoc } \\
\text { Minatitlan } \\
\text { San Gabriel } \\
\text { Suchitlàn } \\
\end{array}$ & $\begin{array}{l}1,775 \\
1,601 \\
294,828 \\
8,921 \\
4,665 \\
3,961 \\
4,190 \\
4,083 \\
\end{array}$ & $\begin{array}{l}\text { Tourism } \\
\text { Trade } \\
\text { Farming: vegetables, sugar cane, corn, } \\
\text { grassland, poultry and pigs } \\
\text { Ranching: cattle, sheep and goat }\end{array}$ & $\begin{array}{l}\text { Zapotitlán de Vadillo-Colima } \\
\text { Colima-Puerto Vallarta }\end{array}$ \\
\hline 0.5 & $\begin{array}{l}\text { El Grullo } \\
\text { Atemajac } \\
\text { Chiquilistlan } \\
\text { Coquimatlàn } \\
\text { Ejutla } \\
\text { El Destacamento } \\
\text { El Limón } \\
\text { Juchitlan } \\
\text { San Clemente } \\
\text { San Gabriel } \\
\text { San Juan de Amula } \\
\text { Tonaya } \\
\text { Union de Guadalupe } \\
\text { Unión de Tula }\end{array}$ & $\begin{array}{l}19,364 \\
28 \\
3,416 \\
11,374 \\
1,229 \\
163 \\
2,965 \\
3,403 \\
1,078 \\
4,190 \\
488 \\
3,238 \\
873 \\
8,589\end{array}$ & $\begin{array}{l}\text { Tourism } \\
\text { Trade } \\
\text { Farming: vegetables, sugar cane, corn, } \\
\text { grassland, pigs and poultry } \\
\text { Ranching: cattle, sheep and goat }\end{array}$ & $\begin{array}{l}\text { Colima-Coquimatlan } \\
\text { Barra de Navidad-El Grullo } \\
\text { Ixtlahuacán-Cuquío }\end{array}$ \\
\hline 0.01 & $\begin{array}{l}\text { Coquimatlán } \\
\text { Puerto Vallarta } \\
\text { Sayula } \\
\text { Tecomàn }\end{array}$ & $\begin{array}{l}11,374 \\
177,830 \\
27,311 \\
76,166\end{array}$ & $\begin{array}{l}\text { Tourism } \\
\text { Trade } \\
\text { Industry: cement and gypsum } \\
\text { Farming: sugar cane, limes, coconuts, } \\
\text { tamarind, mango, banana, tobacco, } \\
\text { coffee, sweet corn, dry beans, } \\
\text { legumes, pigs, poultry } \\
\text { Ranching cattle and horses }\end{array}$ & $\begin{array}{l}\text { Pacific Highway } \\
\text { Guadalajara-Puerto Vallarta }\end{array}$ \\
\hline
\end{tabular}

Table 10. Scenarios 6 and 7. Localities, populations, main economic activities and roads which would be affected by different ash-fall levels during an eruption occurring in September or November and December.

are more than 56,208 people living, who would have eye, skin and respiratory problems. The sugar cane, vegetable and forage grass would be affected. The livestock would get sick by eating pasture contaminated with ash.

The Guadalajara-Manzanillo and El Grullo-Ciudad Guzman roads would have traffic problems due to a lack of visibility. The power stations and radio and television microwave stations in El Grullo and Mazamitla would have interference problems.

\section{$0.1 \mathrm{~cm}$}

From $0.1 \mathrm{~cm}$ to $0.5 \mathrm{~cm}$ of ash would be expected between $160 \mathrm{~km}$ and $390 \mathrm{~km}$ west of CV, an area with more than 125,235 people, living in Armeria, Manzanillo, Cuyutlán and small towns. The population would suffer problems similar to those in previous scenarios with $0.1 \mathrm{~cm}$ of ash. The ash would contaminate the salt production in Cuyutlan. The effects on some agricultural areas would be minimal.

The Colima-Manzanillo highway would have traffic problems due to slippery roads and the low visibility caused by ash. The international airport in Manzanillo, which handles 8,004 flights/year, would suspend operations for hours or days. In this area, there are also two thermoelectric plants in Manzanillo, and the ash would increase atmospheric pollution there.

\section{$0.01 \mathrm{~cm}$}

From $0.01 \mathrm{~cm}$ to $0.1 \mathrm{~cm}$ of ash would be expected between $390 \mathrm{~km}$ and $725 \mathrm{~km}$ from CV. In this area, there are more than 253,996 inhabitants, in Puerto Vallarta, Tecoman and Sayula. Ash would also fall in the Pacific Ocean area, affecting ships. The tourist and maritime activities in this area would also be affected for hours or days.

The microwave stations in Puerto Vallarta and in 
Tecoman would have few problems, as would the highways of the Pacific area; however, for the airport in Puerto Vallarta that handles 38,892 flights / year, the fine ash would interrupt flights and airport operations.

\section{Scenario 7}

During November and December, the dominant winds blow westward, with slight variations to the west-southwest. Therefore, similar impacts will be expected to those depicted in scenario 6, although the areas affected would be further south, perhaps producing more ash on Colima and Tecoman than in September (Figure 10). The scenarios are summarized in Table 11.

\section{Arrival Time}

It is possible to estimate the time of arrival of the ash in the main cities. Ciudad Guzman would expect about 15 $\mathrm{cm}$ of ash in about 10 minutes if the Plinian eruption occurs from January to May or in October; (Table 12). In Guadalajara, about $0.5 \mathrm{~cm}$ would arrive in less than 1 hour, while in León, $0.1 \mathrm{~cm}$ would begin falling after nearly 2 hours from January to March and in May. Cities like Mexico City and Puebla would have ash-fall 5 hours and 6 hours 16 minutes after of an eruption, if the event occurs in April or in October. Tourist cities such as Manzanillo, Puerto Vallarta and Mazatlan would expect between $0.1 \mathrm{~cm}$ and $0.01 \mathrm{~cm}$ of ash 35 minutes, and 2 hours and 4 hours,

\begin{tabular}{|c|c|c|c|c|c|}
\hline $\begin{array}{l}\text { Scenario and } \\
\text { dominant wind } \\
\text { direction }\end{array}$ & $\begin{array}{c}\text { Ash } \\
\text { thickness } \\
\text { (cm) }\end{array}$ & City & $\mathbf{P}$ & Airport & $\mathbf{F}$ \\
\hline \multirow[t]{6}{*}{1 - NNE } & 0.5 & Guadalajara & 1 & Miguel Hidalgo y Costilla & 1 \\
\hline & 0.1 & Leon & 1 & El Bajío & 2 \\
\hline & 0.01 & Aguascalientes & 2 & Jesús Terán Pereda & 2 \\
\hline & & San Luis Potosí & 3 & Ponciano Arriaga & 2 \\
\hline & & Victoria Ciudad & 3 & Gral. Pedro José Méndez & no data \\
\hline & & Celaya & 3 & Celaya & \\
\hline \multirow[t]{11}{*}{2 - $E$} & $>1.0$ & Colima & 3 & Miguel de la Madrid $\mathrm{H}$ & 3 \\
\hline & 0.5 & Zamora & 3 & Zamora & 3 \\
\hline & 0.1 & Morelia & 2 & Francisco Mujica & 3 \\
\hline & & Uruapan & 3 & Ignacio López Rayón & 3 \\
\hline & 0.01 & Cuernavaca & 2 & Gral. Mariano Matamoros & no data \\
\hline & & Mexico City & 1 & Benito Juárez & \\
\hline & & Pachuca & 3 & Juan G. Villasana & no data \\
\hline & & Puebla & 1 & Hermanos Serdán & 2 \\
\hline & & Querétaro & 2 & Querétaro & \\
\hline & & Toluca & 1 & Adolfo Lopez Mateos & no data \\
\hline & & Celaya & 3 & Celaya & \\
\hline \multirow[t]{6}{*}{3 - NE } & 0.5 & Guadalajara & 1 & Miguel Hidalgo y Costilla & 1 \\
\hline & 0.01 & Aguascalientes & 2 & Jesús Terán Pereda & 2 \\
\hline & & Saltillo & 2 & Ramos Arizpe & 2 \\
\hline & & San Luis Potosi & 3 & Ponciano Arriaga & 2 \\
\hline & & Zacatecas & 3 & Gral. Leobardo C. Ruiz & 3 \\
\hline & & Zamora & 3 & Zamora & 3 \\
\hline \multirow[t]{3}{*}{4 - NNW } & 0.5 & Guadalajara & 1 & Miguel Hidalgo y Costilla & 1 \\
\hline & 0.01 & Durango & 2 & Gral. Guadalupe Victoria & 2 \\
\hline & & Tepic & 3 & Amado Nervo & 2 \\
\hline \multirow[t]{6}{*}{5 - NW } & 0.5 & Guadalajara & 1 & Miguel Hidalgo y Costilla & 1 \\
\hline & 0.1 & Puerto Vallarta & 3 & Gustavo Díaz Ordaz & 2 \\
\hline & & Tepic & 3 & Amado Nervo & 2 \\
\hline & 0.01 & Manzanillo & 3 & Manzanillo & \\
\hline & & Mazatlán & 3 & Rafael Buelna & no data \\
\hline & & Colima & 3 & Miguel de la Madrid $\mathrm{H}$ & 3 \\
\hline $6-W$ & $>1.0$ & Colima & 3 & Miguel de la Madrid $\mathrm{H}$ & 3 \\
\hline \multirow[t]{2}{*}{7 - WSW } & 0.1 & Manzanillo & 3 & Manzanillo & 3 \\
\hline & 0.01 & Puerto Vallarta & 3 & Gustavo Díaz Ordaz & 2 \\
\hline
\end{tabular}

Table 11. Cities and airports which would be affected by future Plinian eruption. P population 1: >1,000,000; 2: 500,000-1,000,000; 3: 100,000-500,000. F number of flights/year (2006), 1: >50,000; 2: 10,000-50,000; 3: 1,000-10,000. 

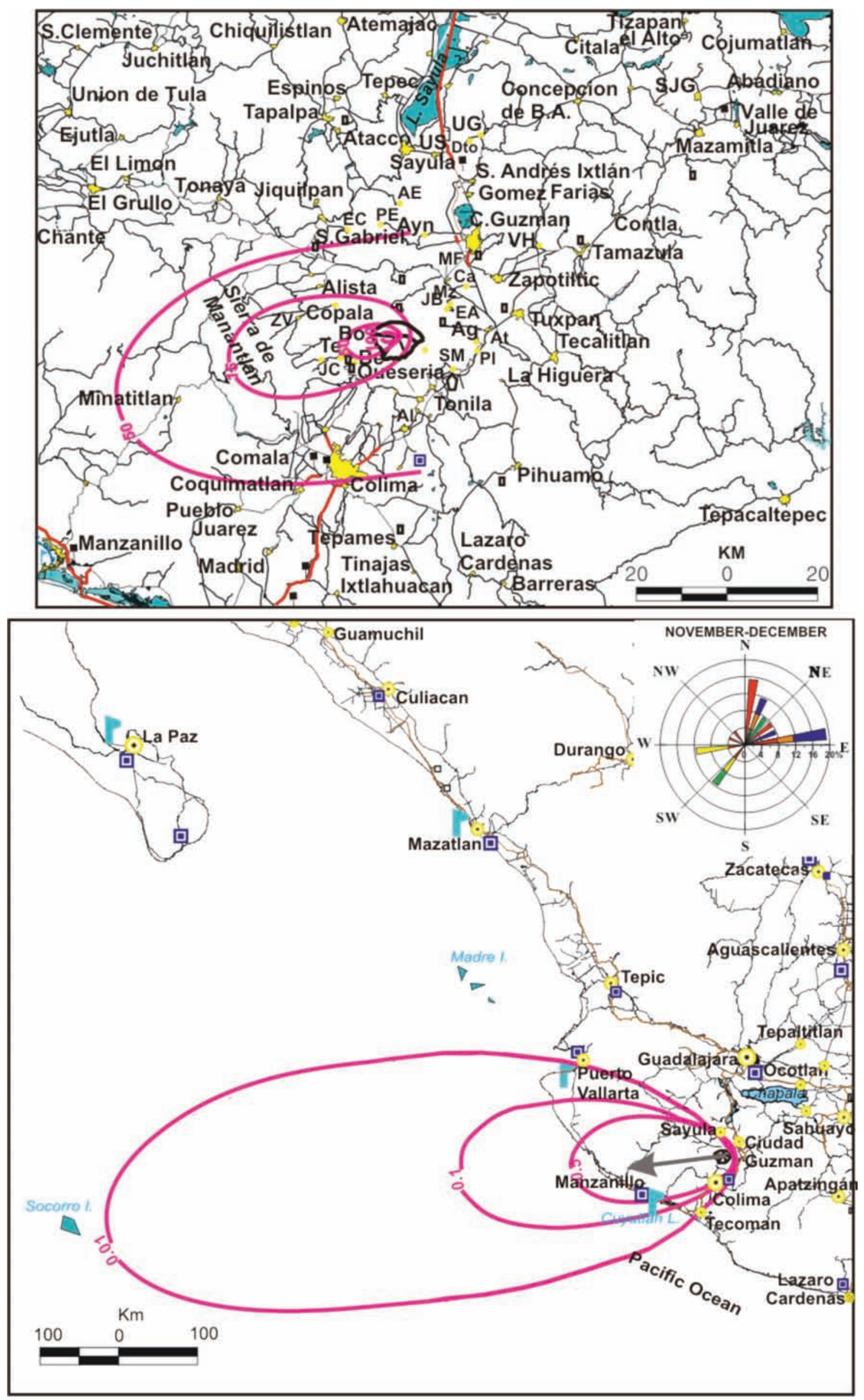

Figure 10. Scenario 7. For an eruption in November or December, showing the west-southwest area and the Pacific Coast that would be affected by a future Plinian eruption. For details, see legend to Figure 4. 


\begin{tabular}{|c|c|c|c|}
\hline \multirow{2}{*}{$\begin{array}{l}\text { Scenario/month } \\
\text { 1-January to March }\end{array}$} & City & \multicolumn{2}{|c|}{ Estimated Time to Ash Fall } \\
\hline & & $>150 \mathrm{~km} / \mathrm{h}$ & $25 \mathrm{~km} / \mathrm{h}$ \\
\hline & Ciudad Guzman & $10^{\prime}$ & 1h 02' \\
\hline & Guadalajara & 56 & $5 \mathrm{~h} 37$ \\
\hline & Aguascalientes & $2 \mathrm{~h} 08^{\prime}$ & $12 \mathrm{~h} 49^{\prime}$ \\
\hline & Leon & 1h $50^{\prime}$ & $11 \mathrm{~h}$ \\
\hline & Saltillo & $4 \mathrm{~h} 50^{\prime}$ & $29 \mathrm{~h}$ \\
\hline & San Luis Potosi & 2h 39' & $15 \mathrm{~h} 52^{\prime}$ \\
\hline 2- April and October & & $100 \mathrm{~km} / \mathrm{h}$ & $50 \mathrm{~km} / \mathrm{h}$ \\
\hline & Ciudad Guzman & $15^{\prime} 50^{\prime \prime}$ & $31^{\prime} 21^{\prime \prime}$ \\
\hline & Colima & $18^{\prime}$ & 36 \\
\hline & Mexico City & $5 \mathrm{~h} 03^{\prime}$ & 10h 06' \\
\hline & Morelia & $6 \mathrm{~h} 15^{\prime}$ & $12 \mathrm{~h} 30^{\prime}$ \\
\hline & Puebla & $6 \mathrm{~h} 16^{\prime}$ & $12 \mathrm{~h} 32^{\prime}$ \\
\hline & Querétaro & $4 \mathrm{~h}$ & $8 \mathrm{~h}$ \\
\hline & Uruapan & 1h 48' & $3 \mathrm{~h} 36^{\prime}$ \\
\hline & Zamora & $1 \mathrm{~h} 27^{\prime}$ & $2 \mathrm{~h} 54^{\prime}$ \\
\hline 3-May (NNE) & & $50 \mathrm{~km} / \mathrm{h}$ & $25 \mathrm{~km} / \mathrm{h}$ \\
\hline & Aguascalientes & $6 h 24^{\prime}$ & $12 \mathrm{~h} \mathrm{49}$ \\
\hline & Ciudad Guzman & $31^{\prime}$ & 1h 02 \\
\hline & Guadalajara & $2 \mathrm{~h} 48^{\prime}$ & $5 \mathrm{~h} 37$ \\
\hline & San Luis Potosi & $7 \mathrm{~h} 55$ & $15 \mathrm{~h} 52$ \\
\hline & Zacatecas & 7h48' & $15 \mathrm{~h} 37^{\prime}$ \\
\hline & Zamora & 2h 54' & 5 h 49' \\
\hline 4-May (NNW) & & $100 \mathrm{~km} / \mathrm{h}$ & $50 \mathrm{~km} / \mathrm{h}$ \\
\hline & Colima & 18 & $36^{\prime}$ \\
\hline & Guadalajara & 1h 24 & $2 \mathrm{~h} 48^{\prime}$ \\
\hline & Manzanillo & 52 & $1 \mathrm{~h} 45^{\prime}$ \\
\hline & Mazatlan & $4 \mathrm{~h} 44^{\prime}$ & 9h 05 ' \\
\hline & Puerto Vallarta & $2 \mathrm{~h} 06^{\prime}$ & 4h 12 \\
\hline & Tepic & $1 \mathrm{~h} 32^{\prime}$ & $3 \mathrm{~h} \mathrm{06}$ \\
\hline 5-June to August & & $100 \mathrm{~km} / \mathrm{h}$ & $50 \mathrm{~km} / \mathrm{h}$ \\
\hline & Colima & $18^{\prime}$ & $36^{\prime}$ \\
\hline & Manzanillo & $52^{\prime}$ & 1h $45^{\prime}$ \\
\hline & Puerto Vallarta & $2 \mathrm{~h} 06$ & $4 \mathrm{~h} 12$ \\
\hline 6-September & & $50 \mathrm{~km} / \mathrm{h}$ & $25 \mathrm{~km} / \mathrm{h}$ \\
\hline & Colima & $36^{\prime}$ & 1h 12' \\
\hline & Manzanillo & 1h $45^{\prime}$ & 3h $29^{\prime}$ \\
\hline & Puerto Vallarta & 4h 12' & $8 \mathrm{~h} 24$ \\
\hline 7-Nov-December & & $>150 \mathrm{~km} / \mathrm{h}$ & $25 \mathrm{~km} / \mathrm{h}$ \\
\hline & Colima & $12^{\prime}$ & 1h 12' \\
\hline & Manzanillo & 35 & $3 \mathrm{~h} 29^{\prime}$ \\
\hline & Puerto Vallarta & $1 \mathrm{~h} 24^{\prime}$ & $8 \mathrm{~h} 24$ \\
\hline
\end{tabular}

Table 12. Estimated arrival times for ash in the main cities, according to month of eruption and maximum and minimum wind speeds.

respectively, after of the eruption onset, if it is from May to December.

\section{Conclusions}

Historical analysis has shown that $\mathrm{CV}$ has a cyclic behaviour, with a VEI 4 Plinian eruption that destroys the central dome occurring approximately every 100 years. The recurrence interval of these Plinian eruptions and similarities between the present-day activity and that which preceded the 1913 eruption indicate that there might be another eruption of this type in the near future.

Our analysis of wind data from 1990 to 2005 shows that during a Plinian eruption the ash would be dispersed in different quadrants throughout the year. The scenarios show that from January to March, ash-fall hazard zones are situated to the northeast of $\mathrm{CV}$, in April and October towards the east, and in May the areas affected would be mainly to the north-northeast or north-northwest. In an eruption occurring from June to August, the ash would travel towards the northwest, in September, towards the west, and in November and December, towards the west-southwest. The wind directions at the time could fluctuate and modify the scenarios in any secondary directions.

The scenarios with a major probability of occurrence are 1 and 2 during January to March, and April and October, as the winds show major stability. The northeastern and eastern areas are more vulnerable because of the greater density of the populations in those area. The immediate effects on the local population would be respiratory problems and psychological stress. The agricultural and livestock sectors would suffer serious financial losses. Cattle would require supplementary feed, due to contamination of pastures because of the ash-fall. The biggest impact would be on farmer incomes due to the damage the ash would cause to pastures, vehicles and buildings. Likewise, the telecommunications stations on the northern flank of the Nevado Volcano and the seismic and visual monitoring equipment at Nevado, $5.3 \mathrm{~km}$ from the CV crater, would be destroyed. The industrial activities of the Queseria sugar mill, the Atenquique paper mill, and the cement plants in Zapotiltic would halt due to the obstruction of their chimneys and the abrasion of any machinery located outside. The Zapotlan Lagoon and Chapala, Cuitzeo and Patzcuaro lakes would have serious contamination by silting and modifications to the conditions of $\mathrm{pH}$ and nutrients.

The international airports of Guadalajara and Aguascalientes, San Luis Potosí, León, México D.F., and Zacatecas with more 10,000 flights/year, and the national airports of Celaya, Zamora and Colima Uruapan with less than 10,000 flights/year might forced to interrupt flights for hours or days, and would require clean-up operations on the runways and aircraft. The permanently busy Guadalajara-Manzanillo highway would be blocked by ash and lack of visibility.

Similar effects would be expected in scenarios 4, 5, 6 and 7 , with the western areas at risk in the summer, and the tourist and commercial ports of Manzanillo, Puerto Vallarta and Mazatlán would be affected during high season. The salt industry in Cuyutlán and the thermoelectric power stations in Manzanillo and Tepic would be affected by fine ash. The airports of Puerto Vallarta, Manzanillo, Mazatlán, Durango, Colima and Tepic would be forced to close operations.

Acknowledgements. The authors would like to thank Don Melchor Urzua, Director of Civil Protection at Colima, and Gabriel Reyes, Head of the Colima Volcano Observatory, for their kind assistance and recommendations while in Colima. The people in the area were always helpful with the study, and especially Marisela Sandoval. The Universidad Nacional Autónoma de Mexico funded this study through projects from DGAPA (PAPIIT) and the Instituto de Geofisica. The authors would also like to acknowledge the field assistance of their students, Amiel Nieto, Mirna Garcia and Dorilen Camacho. 


\section{References}

Aceves, Q.J.F., A.L. Martin Del Pozzo and B.J. López (2007). Volcanic hazard zonation of the Nevado de Toluca Volcano, Central Mexico, Nat. Hazards, 41 (1), 159-180; doi: 10.1007/s11069-006-9029-6.

Andronico, D., S. Branca, S. Calvari, M.R. Burton,, T. Caltabiano, R.A. Corsaro, P. Del Carlo, G. Garfi, L. Lodato, L. Miraglia, F. Murè, M. Neri, E. Pecora, M. Pompilio, G. Salerno and L. Spampinato (2005). A multidisciplinary study of the 2002-2003 Etna eruption: insights into a complex plumbing system, B. Volcanol., 67 (4), 314-330.

Arreola, J.M. (1915). Catálogo de las erupciones antiguas del Volcán de Colima, Memorias de la Sociedad Antonio Alzate, 32, 443-481.

Bárcena, M. (1887). Informe sobre el estado actual del Volcán de Colima, Anales del Ministerio de Fomento, México, 328-365.

Bretón, M., J. Ramírez and C. Navarro (2002). Summary of the historical eruptive activity of Volcán de Colima, Mexico, 1519-2000, J. Volcanol. Geoth. Res., 117, 21-46.

Carey, S. and R.S.J. Sparks (1986), Quantitative models of the fallout and dispersal of tephra from volcanic eruption columns, B. Volcanol., 48, 109-125.

Carey, S. and H. Sigurdsson (1989). The intensity of plinian eruptions, B. Volcanol., 51, 28-40.

Carey, R.J., B.F. Houghton and T. Thordarson (2010). Tephra dispersal and eruption dynamics of wet and dry phases of the 1875 eruption of Askja Volcano, Iceland, B. Volcanol., 72 (3), 259-278; doi: 10.1007/s00445-009-0317-3.

Casadevall, T.J. (1992). Volcanic hazards and aviation safety, F.A.A. Aviation Safety Journal, 2 (3), 1-11.

Casadevall, T.J. (1994). The 1989-1990 eruption of Redoubt Volcano, Alaska: Impacts on Aircraft operations, J. Volcanol. Geoth. Res., 62 (1-4), 301-316.

Ciudad Real, A. de (1976). Tratado curioso y docto de las grandezas de la Nueva España, 2nd ed. (1st ed. Madrid, 1872), UNAM México, 2 voll.

Cook, R.J., J.C. Barron, R.I. Papendick and G.J. Williams III (1981). Impact on Agriculture of the Mount St. Helens Eruptions, Science, 211 (4477), 16-22; doi: 10.1126/science. 211.4477.16.

Cortes, A., V.H. Garduno, C. Navarro, J.C. Komorowski, R. Saucedo, J.L. Macias and J.C. Gavilanes (2005). Carta Geológica del Complejo Volcánico de Colima, Con Geología del Complejo Volcánico de Colima, Cartas geológicas y mineras 0185-4798, vol.10.

Costa, A., F. Dell'Erba., M.A. Di Vito, R. Isaia, G. Macedonio, G. Orsi and T. Pfeiffer (2009). Tephra fallout hazard assessment at the Campi Flegrei caldera (Italy), B. Volcanol., 71 (3), 259-273; doi: 10.1007/ s00445-008-0220-3.

De la Cruz, S. (1993). Random patterns of activity of Colima Volcano, Mexico, J. Volcanol. Geoth. Res., 55, 51-68.

Delgado, G.H. (2001). Patrones de viento en las cercanías del
Volcán Popocatépetl, los productos balísticos y sus efectos, In: Las cenizas volcánicas del Popocatépetl y sus efectos para la aeronavegación e infraestructura aeroportuaria, Centro Nacional de Prevención y Desastres, Instituto de Geología, UNAM México, 51-79.

De Vita S., G. Orsi, L. Civetta, A. Carandente, M. D'Antonio, A. Deino, T. Di Cesare, R.V. Fisher, R. Isaia, E. Marotta, A. Necco, M.H. Ort, L. Pappalardo, M. Piochi, J. Southon (1999). The Agnano-Monte Spina eruption (4100 years B.P.) in the restless Campi Flegrei caldera, J. Volcanol. Geoth. Res., 91, 269-301.

Díaz, S. (1906). Efemérides del Volcán de Colima (1893-1905), Secretaria de Fomento, México, 168 pp.

Dirección General de Estadística (1918). Censo General de Habitantes 1910, Jalisco, México, 179 pp.

Flores, J.A. (1987). Las erupciones del Volcán de Colima, Colección: Cuaderno de difusión científica, Instituto de Geografía y Estadística, Universidad de Guadalajara, 10, 7-52.

Folch, A. and A. Felpeto (2005). A coupled model for dispersal of tephra Turing explosive eruptions, J. Volcanol. Geoth. Res., 145, 337-349.

Fonseca, A.R. (2003). Efectos Ambientales de la erupcion de 1913 del Volcan de Colima, y sus proyecciones a futuro, Tesis de maestria, Universidad Nacional Autonoma de Mexico, 76 pp.

Fonseca, R., A.L. Martin Del Pozzo, I. Perez, M. Garcia (2007). Ash fall impact from Colima Volcano during may and June 2005, In: El Chichon volcano: twenty-five years later. A commemorative conference, edited by J.M. Espindola, J.L. Arce and J.L. Macias, Universidad Nacional de México, IAVCEI, 31.

García-Acosta, V. and R.G. Suárez (1996). Los sismos en la historia de México, Fondo de Cultura Económica. Mexico, 718 pp.

González, P., A.L. Martin Del Pozzo, A.J. Panohaya and J.A. Gante González (1993). Estudio de la sismicidad y deformación del Volcán de Colima durante la crisis de abril de 1991, Geofís. Int., 32 (4), 671-682.

Guffanti, M., G. Mayberry, T.J. Casadevall and R. Wunderman (2009). Volcanic hazard to airports, Nat. Hazards, 51 (2), 287-302; doi: 10.1007/s11069-008-9254-2.

GVN (2001). Global Volcanic Program, Bulletin of the Global Volcanism Network; http: / /www.volcano.si.edu/reports / bulletin/.

INEGI, Instituto Nacional de Estadística, Geografía e Informática (2005). II Conteo de población y vivienda Resultados Definitivos, tabulados básicos; http: / /www.inegi.org.mx/ est/contenidos/espanol/sistemas / conteo2005/.

INEGI, Instituto Nacional de Estadística, Geografía e Informática (2007). Anuario estadístico por estado; http: / / www.inegi.org.mx/ est / contenidos / espanol/sistemas / Aee07/ estatal / col/index.htm.

Houghton, B.F., C. Bonadonna, C.E. Gregg, D.M. Johnstonb, 
W.J. Cousinsb, J.W. Colec and P. Del Carlo (2006). Proximal tephra hazards: Recent eruption studies applied to volcanic risk in the Auckland volcanic field, New Zealand, J. Volcanol. Geoth. Res., 155 (1-2), 138-149.

Horwell, C. and P. Baxter (2006). The respiratory health hazards of volcanic ash: a review for volcanic risk mitigation, B. Volcanol., 69, 1-24; doi: 10.1007/s00445-006-0052-y.

Luhr, J.F. and I.S.E. Carmichael (1982). The Colima volcanic complex, Mexico, Part III: Ash and scoria-fall deposits from the upper slopes of Volcán Colima, Contrib. Mineral. Petr., 80, 262-275.

Luhr, J.F and I.S.E. Carmichael (1990). Geology of Volcán the Colima, Universidad Nacional Autónoma de México, Boletín de Instituto de Geología, 107, 101-107.

Lugo, J., A.L. Martin Del Pozzo and S.L. Vázquez (1993). Estudio Geomorfológico del Complejo de Colima, Geofis. Int., 32 (4), 633-641.

Macedonio, G., A. Costa and A. Folch (2008). Ash fallout scenarios at Vesuvius: Numerical simulations and implications for hazard assessment, J. Volcanol. Geoth. Res., 178, 366-377.

Macias, J.L., R. Saucedo, J.C. Gavilanes,N. Varley, S. Velasco, M. Bursik, V. Vargas and A. Cortéz (2006). Flujos piroclasticos asociados a la actividad explosiva del Volcan de Colima y perspectivas futuras, GEOS, 25 (3), 340-351.

McKnight, D.M., G.L. Feder and A. Stiles (1982). Effects on a blue-green alga of leachates of ash from the May 18 eruption, In: The 1980 eruptions of Mount St. Helens, edited by P.W. Lipman and D.R. Milleneaux, Washington, Geological Survey Professional Paper, 733-741.

Martin Del Pozzo, A.L. and M.V.H. Romero (1988). El volcán de Colima: un estudio sobre riesgo, Litosfera, 2 (1), 43-55.

Martin Del Pozzo, A.L., M. Sheridan, D. Barrera, H.J. Lugo and S.L. Vazquez (1995a). Potencial hazards from Colima Volcano, Geofís. Int., 34 (4), 363-376.

Martin Del Pozzo, A.L., M. Sheridan, D. Barrera, H.J. Lugo and S.L. Vazquez (1995b). Mapa de peligros Volcán de Colima, Universidad Nacional autónoma de México.

Martin Del Pozzo, A.L., R. Fonseca and D. Barrera (2002). El Volcán de Colima, La erupción de 1913, In: Desastres Naturales en América Latina, edited by H.J. Lugo and M. Inbar, Fondo de Cultura Económica, México, 85-100.

Martin Del Pozzo, A.L., M.T. González, P. R. Espinasa-Pereña, M.A. Butron and M. Reyes (2008). Characterization of the recent ash emissions at Popocatepetl Volcano, Mexico, J. Volcanol. Geoth. Res., 170 (1-2), 61-75.

Medina, M.F. (1983). Analysis of the eruptive history of the Volcán de Colima, México (1560-1950), Geofís. Int., 22 (2), 157-178.

Mooser, F. (1961). Los volcanes de Colima, Boletín del Instituto de Geología México, 61, 49-71.

Mota Padilla, M. de la (1742). Historia de la Conquista de la Nueva Galicia, Guadalajara, II, 310.
Navarro, O.C., J.C. Gavilanes and A. Cortés (2002). Movement and emplacement of lava flows at Volcán de Colima, México: November 1998-February 1999, J. Volcanol. Geoth. Res., 117 (1-2), 155-167.

Navarro, O., C.A. Cortes and A.J.A. Téllez (2003). Mapa de Peligros del Volcán de Colima, Universidad de Colima, México.

Nieto, A., A.L. Martin Del Pozzo, R. Fonseca and M. Garcia (2007). Effect of the ash Fall on the Human Health at Colima Volcano During 2005-2006, American Geophysical Union, Spring Meeting 2007, V41A-05.

Pérez de León, J.M. (1789). Descripción del Distrito de Colima y del Corregimiento de San Miguel Xilotlán en 1789, In: Documentos para la historia de Colima: Siglos XVI-XIX, México 1979, 252.

Pfeiffer, T., A. Costa and G. Macedonio (2005). A model for the numerical simulation of tephra fall deposits, J.Geophys. Res., 140 (4), 273-294.

Puga, B.G. (1889). La última erupción de Colima, Memoria Sociedad Científica Antonio Alzate, México, 3, 97-104.

Reyes, D.G and R.S. De la Cruz (2002). Experience in the shortterm eruption forecasting at the Volcán de Colima, México and public response to forecasts, J. Volcanol. Geoth. Res., 117, 121-127.

Robin, C., G. Camus and A. Gougaurd (1991). Eruptive and magmatic cycles at Fuego de Colima Volcano (Mexico), J. Volcanol. Geoth. Res., 45 (3-4), 209-225.

Rodríguez-Elizarrarása, S., C. Siebeb, J.-C. Komorowskib, J.M. Espíndolac and R. Saucedo (1991). Field observations of pristine block and flow deposits emplaced April 16-17 1991 at Volcán de Colima, México, J. Volcanol. Geoth. Res., 48 (3-4), 399-412.

Saucedo, R. (1997). Reconstrucción de la Erupción de 1913 del Volcán de Colma, Tesis de maestría, Posgrado en Ciencias de la Tierra, Instituto de Geofísica, Universidad Nacional Autónoma de México, 185 pp.

Saucedo, R., J.L. Macías, M.I. Bursik, J.C. Mora, J.C. Gavilanes and A. Cortes (2002). Emplacement of pyroclastic flows during the 1998-1999 eruption of Volcán de Colima, México, J. Volcanol. Geoth. Res., 117 (1-2), 129-153.

Saucedo, R., J.L. Macías, J.C. Gavilanes, J.L. Arce, C. Komorowski, J.E. Gardner, G. Valdez-Moreno (2010). Eyewitness, stratigraphy, chemistry, and eruptive dynamics of the 1913 Plinian eruption of Volcán de Colima, México, J. Volcanol. Geoth. Res., 191 (3-4), 149-166; doi: 10.1016/j.jvolgeores.2010.01.011.

Schuster, R. (1982). Effects of the eruptions on civil works and operation in the pacific northwest, In: The 1980 eruptions of Mount St. Helens, edited by P.W. Lipman and D.R. Milleneaux, Washington, Geological Survey Professional Paper, 701-718.

Selva, J., A. Costa, W. Marzocchi and L. Sandri. (2010). BET_VH: exploring the influence of natural uncertain- 
ties on long-term hazard from tephra fallout at Campi Flegrei (Italy), B. Volcanol., 72 (6), 717-733; doi: 10.1007/ s00445-010-0358-7.

Sigurdsson, H., S. Carey, W. Cornell and T. Pescatore (1985). The Eruption of Vesuvius in A.D. 79, Nat. Geo. Res., 1 (3), 332-387.

Smithsonian Institution (1988). Colima, Bulletin of the Global Volcanism Network, 13; http:/ / www.volcano.si.edu/ reports/bulletin/.

Smithsonian Institution (1993). Colima, Bulletin of the Global Volcanism Network, 18; http:/ / www.volcano.si.edu / reports/bulletin/.

Smithsonian Institution (2000). Colima, Bulletin of the Global Volcanism Network; http:/ / www.volcano.si.edu/reports / bulletin/.

Smithsonian Institution (2003). Colima, Bulletin of the Global Volcanism Network; http:/ / www.volcano.si.edu/reports / bulletin/.

Starr, F. and J.M. Arreola (1903). The Recent Eruptions of Colima, J. Geol., 11 (8), 749-761.

Tello, F.A. (1651). Libro segundo de la Crónica Miscelánea de la conquista espiritual y de la Santa Provincia de Xalisco en el Nuevo Reino de la Galicia y Nueva Vizcaya y Descubrimiento del Nuevo México, Guadalajara, 886 pp.

Thorpe, R.A., Gibson, I.L. and J.S. Vízcaino (1977). Andesitic pyroclastic flows from Volcán de Colima, Nature, 265, 724-725.

Vízcaino, J.S. (1993). Notas sobre el Volcán, Geofís. Int., 32 (4), 699-701.

Vizcarra, I.G. (1891). Pequeña cartilla histórica de Colima, Colima, $100 \mathrm{pp}$.

Waitz, P. (1932). Datos históricos y bibliográficos acerca del Volcán de Colima, Memoria de la Sociedad Antonio Alzate, 53, 349-384.

Wilson, J., R.S.J. Sparks, T.C. Huang and N.D. Watkins (1978). The control of volcanic column heights by eruption energetics and dynamics, J. Geophys. Res., 83, 1829-1836.

Zobin, V.M., J.F. Luhr, Y.A. Taran, M. Breton, A. Cortés, S. De la Cruz-Reyna, T. Dominguez, I. Galindo, J. Gavilanes, J. Muñiz, C. Navarro, J. Ramirez, G. Reyes, M. Ursua, J. Velasco, E. Alatorre and H. Santiago (2002). Overview of the 1997-2000 activity of Volcán de Colima, México, J. Volcanol. Geoth. Res., 117, 1-19.

\footnotetext{
${ }^{\star}$ Corresponding author: Rita Fonseca, Instituto de Geofisica, Universidad Nacional Autónoma de México, Ciudad Universitaria, Coyoacan Mexico D.F., Mexico; email: rifon@geofisica.unam.mx. 